\title{
Chromatin Landscape Defined by Repressive Histone Methylation during Oligodendrocyte Differentiation
}

\author{
미ia Liu, ${ }^{1}$ Laura Magri, ${ }^{1}$ Fan Zhang, ${ }^{2}$ Nidaa 0. Marsh, ${ }^{1}$ Stefanie Albrecht, ${ }^{3}$ Jimmy L. Huynh, ${ }^{1,4}$ @ Jasbir Kaur, ${ }^{1}$ \\ Tanja Kuhlmann, ${ }^{3}$ Weijia Zhang, ${ }^{2}$ Paul A. Slesinger, ${ }^{1}$ and $\odot$ Patrizia Casaccia ${ }^{1,4}$ \\ ${ }^{1}$ Department of Neuroscience, ${ }^{2}$ Bioinformatics Laboratory, Department of Medicine, and ${ }^{4}$ Department of Genetics and Genomic Sciences, Icahn School of \\ Medicine at Mount Sinai, New York, New York 10029, and ${ }^{3}$ Institute of Neuropathology, University Hospital Münster, D-48149 Münster, Germany
}

\begin{abstract}
In many cell types, differentiation requires an interplay between extrinsic signals and transcriptional changes mediated by repressive and activating histone modifications. Oligodendrocyte progenitors (OPCs) are electrically responsive cells receiving synaptic input. The differentiation of these cells into myelinating oligodendrocytes is characterized by temporal waves of gene repression followed by activation of myelin genes and progressive decline of electrical responsiveness. In this study, we used chromatin isolated from rat OPCs and immature oligodendrocytes, to characterize the genome-wide distribution of the repressive histone marks, $\mathrm{H} 3 \mathrm{~K} 9 \mathrm{me} 3$ and $\mathrm{H} 3 \mathrm{~K} 27 \mathrm{me} 3$, during differentiation. Although both marks were present at the OPC stage, only H3K9me3 marks (but not H3K27me3) were found to be increased during differentiation, at genes related to neuronal lineage and regulation of membrane excitability. Consistent with these findings, the levels and activity of H3K9 methyltransferases (H3K9 HMT), but not H3K27 HMT, increased more prominently upon exposure to oligodendrocyte differentiating stimuli and were detected in stage-specific repressive protein complexes containing the transcription factors SOX10 or YY1. Silencing H3K9 HMT, but not H3K27 HMT, impaired oligodendrocyte differentiation and functionally altered the response of oligodendrocytes to electrical stimulation. Together, these results identify repressive H3K9 methylation as critical for gene repression during oligodendrocyte differentiation.
\end{abstract}

Key words: ChIP-seq; epigenetics; myelin; potassium channel

\section{Introduction}

Oligodendrocyte progenitors (OPCs) are proliferating cells with the ability to generate oligodendrocytes (OLs) and possibly other lineage cells (Richardson et al., 2011). Understanding the mechanisms leading transitions from OPCs to OLs is important for elucidating mechanisms of neurodevelopmental disorders and for myelin repair. Changes of nuclear chromatin components (Marin-Husstege et al., 2002; Shen et al., 2005; Liu et al., 2012; Yu et al., 2013) as well as transcriptional networks (Emery, 2010; Zhang et al., 2014) and microRNAs (Dugas et al., 2010) have been reported to regulate this transition. This study characterizes indepth molecular mechanisms of gene repression occurring during OPC differentiation.

We previously reported the importance of the histone deacetylases HDAC1 and HDAC2 (Shen et al., 2008b) and the transcription factor YY1 in the downregulation of gene expres-

\footnotetext{
Received June 25, 2014; revised Sept. 24, 2014; accepted 0ct. 1, 2014.

Author contributions: J.L. and P.C. designed research; J.L., L.M., N.O.M., S.A., J.K., T.K., and P.A.S. performed research; J.L., L.M., F.Z., N.O.M., S.A., J.L.H., T.K., W.Z., P.A.S., and P.C. analyzed data; J.L. and P.C. wrote the paper.

This work was supported by National Institute of Neurological Disorders and Stroke Grants 2R37NS042925-10 and R01NS52738 to P.C. and National Multiple Sclerosis Society Grant FG1874-A-1 to J.L. We thank Dr. Anne Schaefer for stimulating discussions; Dr. Phil Horner and Don Maris for providing important input; Dr. V. Gallo for the gift of the Cnp-EGFP line; and Dr. M. Wegner for the gift of SOX10 antibody.

The authors declare no competing financial interests.

Correspondence should be addressed to Dr. Patrizia Casaccia, Department of Neuroscience, Icahn School of Medicine at Mount Sinai, 1428 Madison Avenue, New York, NY 10029. E-mail: patrizia.casaccia@mssm.edu.

DOI:10.1523/JNEUROSCI.2606-14.2015

Copyright $\odot 2015$ the authors $\quad 0270-6474 / 15 / 350352-14 \$ 15.00 / 0$
}

sion at the early stage of OPC differentiation (He et al., 2007). However, histone deacetylation was transient (Shen et al., 2005) and reversible, thereby rendering unlikely that acetylation per se would be sufficient for differentiation. In this study, we hypothesized that more stable repressive histone modifications (Rice and Allis, 2001), such as the methylation of lysine residues K9 and/or $\mathrm{K} 27$ on histone $\mathrm{H} 3$, contribute to the differentiation of OPC into OLs. One possibility is that progressive lineage restriction adopts a "generalized" mechanism of repression, regardless of the cell type. The other possibility is that distinct mechanisms of repression are used by cells to transition from an undifferentiated state to a lineage-specific differentiated state. This study was designed to ask this question in the OL lineage, by analyzing both H3K27 trimethylation (H3K27me3), which has been implicated in restriction of multipotentiality in stem cells (Bernstein et al., 2006), and H3K9 trimethylation (H3K9me3), which has been associated with transcriptional repression and heterochromatin formation (Volpe et al., 2002).

OPCs have been shown to receive direct synapses from glutamatergic or GABAergic terminals and have the ability to respond to neurotransmitters through the activation of ionotropic receptors and voltage-gated ion channels (Chittajallu et al., 2004; Ge et al., 2006; Kukley et al., 2007; Ziskin et al., 2007; Káradóttir et al., 2008; De Biase et al., 2010). As these cells mature, they lose electrical responsiveness and become myelin-forming OLs. It is unclear whether loss of membrane excitability is dependent on neuronal contact or intrinsic to the differentiation process per se. 
By adopting a genome-wide chromatin immunoprecipitation (ChIP)-sequencing approach, we defined H3K9me3 as the histone mark underlying the transcriptional changes in the electrical properties of the cells. By also investigating the genome-wide distribution of $\mathrm{H} 3 \mathrm{~K} 27 \mathrm{me} 3$, we show that repressive histone methylation marks are not redundant but selectively used by OPCs to silence functionally distinct gene categories, during the transition to myelinating cells. Thus, repression occurs through highly regulated pathways involving distinct post-translational modifications of either lysine 9 or 27 in the tail of histone H3, with each one serving a distinct functional role in contributing to the final refinement of the unmistakable identity of myelinating OLs.

\section{Materials and Methods}

Animals. Cnp-EGFP mice were a generous gift from Dr. Gallo (Children's Hospital Washington, DC). Use of animals in this research was strictly compliant with the guidelines set forth by the US Public Health Service in their policy on Humane Care and Use of Laboratory Animals, and in the Guide for the Care and Use of Laboratory Animals. Mice were maintained under pathogen-free environment at Icahn School of Medicine at Mount Sinai animal facility. All animal procedures received prior approval from the Institutional Animal Care and Use Committee at Icahn School of Medicine at Mount Sinai. Timed pregnancy Sprague Dawley rats and mice were purchased from Charles River Laboratory, and The Jackson Laboratory, respectively. For organotypic cerebellar slice culture, newborn (P0) wild-type CD1 mouse pups of either sex were obtained from Charles River Laboratories. Animal handlings and experiments were performed according to the German animal protection laws (LANUV Nordrhein-Westfalen: AZ 8.87-51.05.20.10.262).

Cell culture and treatment. Rat OPCs were isolated from the cortices of postnatal day 1 (P1) rats of either sex and cultured as described previously (Shen et al., 2008a). Mouse OPCs were isolated from P6-P8 C57Bl6 mice of either sex and cultured as previously described (Cahoy et al., 2008). Briefly, dissociated mouse forebrains were resuspended in panning buffer. To deplete microglia, the single-cell suspension was sequentially panned on two BSL1 panning plates and then incubated on a PDGFR $\alpha$ plate. The adherent cells were trypsinized and plated onto polyD-lysine-coated plates. The cultures were maintained under proliferating conditions by addition of PDGF $(10 \mathrm{ng} / \mathrm{ml})$ and bFGF $(20 \mathrm{ng} / \mathrm{ml})$ and then differentiated by adding L-3,3',5-triiodothyronine sodium salt (T3 hormone, $45 \mathrm{~nm}$ ).

Organotypic cerebellar/cortical slice culture preparation and treatment. Organotypic cerebellar slice cultures were prepared and cultured as previously described (Miron et al., 2010). Briefly, cortices or cerebellum and attached hindbrain were prepared and cut into $300 \mu \mathrm{m}$ sagittal sections using a McIlwain tissue chopper. Slices were separated and transferred on Millicell-CM culture inserts (Millipore) in 6-well plates. Culture media contained $50 \%$ minimal essential media, $25 \%$ heat-inactivated horse serum, $25 \%$ Earle's balanced salt solution, $6.5 \mathrm{mg} / \mathrm{ml}$ glucose, and penicillin-streptomycin and Glutamax. Slices were transferred into fresh media every $2-3 \mathrm{~d}$. Slices were cultivated for $12 \mathrm{~d}$ in vitro to allow myelination to occur (Birgbauer et al., 2004). To study the influence of Bix01294 during myelination, the slices were treated with different concentrations of Bix-01294 diluted in culture media and replaced every 2-3 d. Control slices were left untreated.

Tissue collection and sectioning. Cnp-EGFP mice of either sex were anesthetized with ketamine/xylazine by intraperitoneal injection and perfused intracardially with $4 \%$ PFA in $0.1 \mathrm{~m}$ phosphate buffer. Brains were removed from the skulls, postfixed overnight, and cryopreserved by sequential immersion of $10 \%, 20 \%$, and $30 \%$ sucrose solution in $0.1 \mathrm{M}$ phosphate buffer, pH 7.4. Brains were then embedded in OCT (Fisher Scientific) and sectioned sagittally $(12 \mu \mathrm{m})$.

For total histone isolation, rat corpora callosa were dissected out under light microscope. Three or four pups of either sex from two separate litters were used in each age group. The tissues were immediately frozen until further use.
Histone isolation and Western blot analysis. Histones were extracted as described previously (Shechter et al., 2007). Briefly, nuclei were isolated by hypotonic lysis buffer containing $10 \mathrm{~mm}$ Tris- $\mathrm{HCl}, \mathrm{pH} 8.0,1 \mathrm{~mm} \mathrm{KCl}$, $1.5 \mathrm{~mm} \mathrm{MgCl}_{2}, 1 \mathrm{~mm}$ DTT, $0.4 \mathrm{~mm}$ PMSF, and protease and phosphatase inhibitors. Pelleted nuclei were extracted by using $0.4 \mathrm{~m}$ sulfuric acid, whereas the supernatant was saved as the cytosolic protein. The acidsoluble histones were precipitated with trichloroacetic acid and resuspended in water. Western blot analysis was performed using appropriate dilution of primary antibodies (anti-H3K9me3, 1:1000, Abcam, ab8898; anti-H3K27me3, 1:2000, Millipore, 07-449; anti-H3, 1:8000, Abcam, ab1791; anti-EHMT2, Cell Signaling Technology, 3306, 1:500; antiEHMT1, 1:1000, R\&D Systems, PP-B0422-00; anti-SUV39H1, 1:1000, Cell Signaling Technology, 8729; anti-nuclear pore complex, 1:4000, Covance, MMS-120P; anti-EZH2, BD Biosciences, 612666, 1:1000) and secondary antibodies (anti-mouse HRP-conjugated, 1:10,000 Vector Laboratories; anti rabbit HRP-conjugated, 1:15,000, GE Healthcare). The immunoreactive bands were detected by ECL Plus Western Blotting Detection System (GE Healthcare). Equal protein loading was guaranteed by probing the blots with antibody against total $\mathrm{H} 3$ or nuclear pore complex. Densitometry of the Western blot protein bands was analyzed using National Institutes of Health ImageJ Software. Statistical analysis was performed using one-way ANOVA followed by Bonferroni's post hoc comparisons tests.

Immunoprecipitation. Whole-cell lysates were extracted from Oli neu cells. Equal amounts of protein $(1 \mathrm{mg})$ were immunoprecipitated for $16-18 \mathrm{~h}$ at $4^{\circ} \mathrm{C}$ using $1 \mu \mathrm{g}$ anti-HDAC1 antibody (Thermo Scientific, PA1-860r). Negative controls were used without adding antibodies. Proteins were separated by SDS-PAGE and transferred to PVDF membrane, followed by Western blot analysis with proper antibodies, including antiEHMT2 (1:500, Cell Signaling Technology, 3306), anti-EHMT1 (1:1000, R\&D Systems), anti-DNMT1 (1:1000, Abcam, ab19905), anti-SOX10 (1:300, AVIVA System Biology, ARP33326), anti-YY1 (1:1000, Abcam, ab58066), anti-CoREST (1:1000, Millipore, 07-455), and anti-EZH2 (1: 1000, BD Biosciences).

Histone methyltransferase activity assay. Fresh nuclear extracts were isolated from cultured mouse primary OL cultures maintained in either proliferating conditions or differentiating conditions (i.e., $45 \mathrm{~nm}$ T3 hormone or $50 \mathrm{ng} / \mathrm{ml}$ bone morphogenetic protein 4 [BMP4]) for $3 \mathrm{~d}$ in vitro using nuclear extraction kit (Active Motif). Histone methyltransferase activity was measured using the $\mathrm{H} 3 \mathrm{~K} 9$ and $\mathrm{H} 3 \mathrm{~K} 27$ methyltransferase activity kit following manufacturer's protocol with fresh nuclear extracts (Epigentek).

Immunohistochemistry and immunocytochemistry. Frozen sections were rehydrated and then antigen-retrieved by incubating in $65^{\circ} \mathrm{C}$ water bath. Sections were permeabilized with blocking buffer $(0.1 \mathrm{~m}$ phosphate buffer, $10 \%$ normal goat serum, Vector Laboratories; $0.1 \%$ gelatin, $1 \%$ BSA, and $0.5 \%$ Triton X-100). Incubation with primary antibodies was performed overnight at $4^{\circ} \mathrm{C}$. Used antibodies include anti-H3K9me3 (Abcam, ab8898, 1:400) and anti-H3K27me3 (Millipore, 07-449, 1:100). After $1 \mathrm{~h}$ incubation with secondary antibodies directly conjugated to specific fluorochromes (Alexa-488, 1:400, or Alexa-568, 1:500, Invitrogen), the sections were counterstained with DAPI (1:10,000; Invitrogen). Stained sections were visualized using a confocal microscopy (LSM710 Meta confocal laser scanning microscope; Zeiss). For immunocytochemistry, cells were fixed with $4 \%$ PFA and washed three times before incubation with primary antibodies, including anti-LHX1 (Abcam, 1:200, ab14554), and anti-Kv2.1 (NeuroMab labs, 1:400,75-014) at $4^{\circ} \mathrm{C}$ overnight. For staining of $\mathrm{O} 4$ and $\mathrm{O} 1$, cells were incubated with appropriate antibodies for $30 \mathrm{~min}$, followed by wash and fixation. For immunohistochemistry of cerebellar slice cultures, slices were fixed in $4 \%$ PFA in PBS for $1 \mathrm{~h}$ and then washed twice in PBS. Afterward, slices were blocked $3 \times 1 \mathrm{~h}$ at room temperature in $1 \mathrm{~mm} / \mathrm{L}$ HEPES, $2 \%$ heat inactivated horse serum, $10 \%$ heat-inactivated goat serum, $1 \%$ BSA, and $0.25 \%$ Triton X-100 in Hanks Balanced Salt Solution. Primary antibodies (rabbit antihuman myelin basic protein (MBP, 1:500; Dako) and mouse anti-human neurofilament (NF, 1:500; Dako) were diluted in blocking solution and incubated on the slices for $48 \mathrm{~h}$ at $4^{\circ} \mathrm{C}$. Slices were washed three times in PBS supplied with $0.05 \%$ Triton X-100 for $1 \mathrm{~h}$. Secondary antibodies were diluted in blocking solution and incubated on slices overnight at 
$4^{\circ} \mathrm{C}$. Goat anti-rabbit Cy3 and goat anti-mouse Cy2 (1:500; Dianova) were used as secondary antibodies. Slices were washed three times and mounted using Fluorescence Mounting Medium (Dako). Two to three optical stacks per stain per slice were acquired using a $63 \times$ objective and a Zeiss LSM 510 microscope. The area ratio of MBP versus NF immunostaining was determined using ImageJ software (National Institutes of Health; http://rsb.info.nih.gov/ij). Briefly, the MBP and NF channels of each image were processed individually by applying the threshold function of ImageJ. Afterward, the stained area was determined applying the analyze particles plug-in of ImageJ; and based on this gained total area value $\left(\mu \mathrm{m}^{2}\right)$, the ratio of $\mathrm{Mbp} / \mathrm{NF}$ was calculated.

Preparation of total cell suspensions and FACS. Cortices were dissected from P2, P5, or P10 Cnp-EGFP mice and wild-type littermates and directly prepared for FACS as previously described (Yuan et al., 2002). Cells were prepared to a density of $5 \times 10^{6}$ cells $/ \mathrm{ml}$ for sorting. Cells were analyzed for light forward- and side-scatter using a FACS INFLUX instrument (BD Biosciences). For EGFP fluorescence, excitation wavelength of the argon ion laser was set at $488 \mathrm{~nm}$, and emission was through a 531/40 nm bandpass filter. Cells from the negative littermates were used to set the background fluorescence, and a size threshold was used to gate out erythrocytes and cellular debris. The sorting pressure was set at 12 psi, and the speed was set to $4000-5000$ cells/s. Sorted cells were rinsed at least once with PBS. RNA was immediately isolated using RNeasy Mini kit (QIAGEN).

$R N A$ isolation and $q R T-P C R$ analysis. RNA was isolated using Trizol reagent (Invitrogen) and cleaned using RNeasy Mini kit (QIAGEN). A total of $500 \mathrm{ng}$ of total RNA was used in $20 \mu \mathrm{l}$ of reverse transcription reaction, using SuperScript RT-PCR kit (Invitrogen) qScript cDNA Supermix. qRT-PCR was performed using PerfeCTa SYBR Green FastMix (Quanta Biosciences) in Applied Biosystem 7900HT Sequence Detection PCR System. The melting curve of each sample was measured to ensure the specificity of the products. Data were normalized to the internal control Gapdh and analyzed using Pfaffl $\Delta \Delta \mathrm{Ct}$ method. Primers used in quantitative PCR for mouse and rat are given in supplemental materials.

Lentiviral shRNA infection. GFP-tagged Ehmt2, Ehmt1, and Suv39h1 lentiviral shRNA transduction particles were purchased from SigmaAldrich. The sequences of the shRNAs targeting genes are given in supplemental materials. ShRNA infection in proliferating primary OPCs was performed in cell suspension. In each infection, a lentivirus encoding a scrambled sequence (SHC002V) against nonmammalian gene target was used as a control, and a lentivirus encoding GFP was used to determine the infection efficiency. Multiplicity of infection of 5 was used for the infection. Polybrene was added at a final concentration of $2 \mu \mathrm{g} / \mathrm{ml}$ to increase the infection efficiency. The virus/cell mixture was incubated in $37^{\circ} \mathrm{C}$ for $2 \mathrm{~h}$ and plated at desired density in growth medium containing PDGF, FGF for $72 \mathrm{~h}$, followed by subsequent experimental treatments. For infecting differentiating OLs, growth medium was replaced with medium containing the viral particles and incubated for $16 \mathrm{~h}$. Puromycin was added at a final concentration of $0.1 \mu \mathrm{g} / \mathrm{ml}$ to select infected cells.

ChIP and ChIP-seq analysis. Chromatin was isolated from rat OPCs and from cells maintained in differentiation medium for $3 \mathrm{~d}$ as previously described (Swiss et al., 2011). The size of the DNA in the sheared chromatin fragments was tested before precipitation by Bioanalyzer to ensure that the majority of fragment size was $200-400 \mathrm{bp}$. Immunoprecipitation was performed with $2.4 \mu \mathrm{g}$ of anti-H3K9me3 (Abcam, ab8898) or anti H3K27me3 (Millipore, 07-449)/1 unit OD260 readings. Two units of chromatin were used per condition. The DNA recovered from chromatin that was not immunoprecipitated was used as input. Chromatin that was immunoprecipitated with protein A-Dynabeads (Invitrogen) in the absence of primary antibody (no $\mathrm{Ab}$ ) was used as a negative control. The primer sequences of qPCR for ChIP are given in supplemental materials.

The input and ChIP samples were sequenced by Illumina HiSeq 2000. ChIP-seq was performed with two biological replicated per condition. The read sequences were generated by analyzing images and base calling using Illumina data analysis pipeline. After QC filtering by FASTX (http://hannonlab.cshl.edu/fastx_toolkit/), only the read with a quality score Q20 in at least $90 \%$ bases were included for analysis. The reads from both input and ChIP samples were first aligned to Rat reference genome (build rn4 from UCSC) using Bowtie alignment method (Langmead et al., 2009). The peaks in the ChIP sample in reference to the input sample in OPCs and OLs were called from read alignments by MACS algorithm (Zhang et al., 2008) and then annotated with gene information, including the distance to transcription start site (TSS) and locations in gene function elements (intron, exon, UTR, upstream or downstream, etc.) from genome mapping information of RefSeq transcripts. The peaks within an interval of $-10 \mathrm{~kb}$ of TSS and $10 \mathrm{~kb}$ of transcription termination site (TTS) of the gene region for OPCs and OLs were compared, and the peaks with a maximum gap of $500 \mathrm{bp}$ were considered to be overlapped. The unique gene list characterized by more than one peak in differentiating OLs was then annotated using the software package Database for Annotation, Visualization and Integrated Discovery (DAVID) (Huang da et al., 2009b, a). The genes were clustered using the functional annotation clustering tool and we only analyzed the ontology terms found in "Biological process" libraries. Gene Ontology enrichment analysis on genes harboring unique or common peaks for OPCs or OLs was performed by Fisher exact test. Finally, the alignment and coverage of ChIPSeq data were visualized by integrative genomics viewer (IGV) program (Thorvaldsdóttir et al., 2013) after input subtraction using methods described previously (Kharchenko et al., 2008).

To compare our ChIP-seq with a published transcriptome database (Zhang et al., 2014), we first converted our ChIP-seq target genes to mouse homologous genes using Ensembl BioMart tool and detected 748 mouse homologous genes of 820 unique $\mathrm{H} 3 \mathrm{~K} 9 \mathrm{me} 3$ target genes in differentiating OLs. A total of 740 of 748 mouse homologous genes were detected in the transcriptome database (Zhang et al., 2014). This is probably because the rest of the genes did not reach the threshold used to analyze the transcriptome database, or a differential expression between species (i.e., rat vs mouse). Next, fold enrichment of neuron or astrocytes was calculated by FPKM of a given cell type (neuron or astrocytes) divided by the average FPKM of all other cell types as described by Zhang et al. (2014). Genes were then ranked by their fold enrichment in each cell type, and genes with fold enrichment $>2$ were identified as neuronenriched genes or astrocyte-enriched genes. To identify the genes that showed decreased expressions upon OPC differentiation, fold enrichment was calculated as the FPKM of OPC divided by the FPKM of myelinating OLs, and the genes with fold change $>2$ were identified.

To compare our ChIP-seq with REST/CoREST target gene, we chose the genes that have a REST or COREST binding site in premyelinating OLs as described by Abrajano et al. (2009). This identified 1818 genes with potential REST/COREST element in premyelinating OLs, and only 58 genes were associated with $\mathrm{H} 3 \mathrm{~K} 9 \mathrm{me} 3$ in differentiating OLs.

To identify transcription factor binding sequence motifs enriched in $\mathrm{H} 3 \mathrm{~K} 9 \mathrm{me} 3$ unique peak sequences in OL, as identified by ChIP-seq, we used MEME-ChIP (Machanick and Bailey, 2011) (http://meme.nbcr. net/meme/cgi-bin/meme-chip.cgi). For analysis using the Genomic Regions Enrichment of Annotations Tool (McLean et al., 2010), the rat ChIP-Seq peak coordinates were converted to the mouse NCBI37/mm9 genomic assembly using the UCSC browser liftover function, and the coordinates were submitted to GREAT using the default basal plus extension setting.

To identify potential transcription factor binding site, ChIP-seq sequences followed by liftover into mouse $\mathrm{mm} 9$ genomic assembly were extracted using genomic coordination and inputted into Genomatix. Potential binding sites were predicted using MatInspector function (Cartharius et al., 2005) provided by Genomatix. Validation of transcription factors ChIP was performed with primary mouse OL cultures using Staph A method described at Dr. Peggy Farmham Laboratory Protocol website (http://farnham. genomecenter.ucdavis.edu/protocol.html). Briefly, 5 units chromatin at OD260 reading was used per ChIP with antibodies against YY1 (Active Motif, 39071) or SOX10 (a generous gift from Dr. Wegner, Universität Erlangen-Nürnberg, Erlangen, Germany).

Electrophysiology. Whole-cell, patch-clamp currents were recorded from $4 \mathrm{~d}$ differentiated GFP-positive OLs infected with either scramble or shRNA against Ehmt 2 and Suv39h1 lentivirus. Cells with appropriate OL morphology and GFP fluorescence were visualized on an inverted Nikon Eclipse TE300 microscope, and currents were recorded with an Axopatch 200B amplifier and Digidata 1320A digitizer (Molecular Devices), sam- 
pled at $10 \mathrm{kHz}$ and filtered at $1 \mathrm{kHz}$. Currents were elicited from individual cells using a voltage step protocol ranging from -100 to $70 \mathrm{mV}$ in 10 $\mathrm{mV}$ steps $(100 \mathrm{~ms})$, holding at $-80 \mathrm{mV}$ Extracellular recording solution contained (in $\mathrm{mm}$ ) the following: $137 \mathrm{NaCl}, 5.37 \mathrm{KCl}, 1.67 \mathrm{CaCl}_{2}, 1.0$ $\mathrm{MgCl}_{2}, 10$ HEPES, 17 glucose, 13.15 sucrose, $\mathrm{pH}$ 7.3, 303 mOsm. Recording electrodes of 5-7 $\mathrm{m} \Omega$ resistances were pulled from borosilicate capillary glass (World Precision Instruments) and filled with intracellular recording solution containing (in $\mathrm{mM}$ ) the following: 130 K-gluconate, $4 \mathrm{MgCl}_{2}$ 1.1 EGTA, 5 HEPES, $3.4 \mathrm{Na}_{2} \mathrm{ATP}, 10 \mathrm{Na}$ creatine $\mathrm{PO}_{4}, 0.1 \mathrm{Na}_{3} \mathrm{GTP}, \mathrm{pH}$ 7.3. Currents were quantified using P.Clamp 8.0 (Molecular Devices), and data are presented as current density $(\mathrm{pA} / \mathrm{pF})$, obtained by dividing membrane current by cell capacitance. Recordings from scramble or sh Ehmt2 + sh Suv39h1 cells $(n=9$ and $n=11$, respectively) were pooled and presented as mean \pm SEM. Cells with whole-cell membrane resistances $<100 \mathrm{M} \Omega$ were excluded from analysis. All recordings were collected at room temperature. Post hoc leak subtraction was performed to exclude nonspecific, voltage-independent conductances from analysis. Recordings were performed with the experimenter blinded to the infection group.

Statistics. One-way ANOVAs were performed to determine significance for Western blotting, immunocytochemistry and immunohistochemistry comparing levels of histones and HMTs at different time points. Assuming that significant main effects were observed $(p<0.05)$, Bonferroni post hoc tests were used to compare selected groups. Student's $t$ tests were used for all other comparisons, including immunocytochemistry and electrophysiology. ChIP-Seq-related statistics are described in the main text. All values included in the figure legends represent mean \pm SEM.

\section{Results}

\section{Increased repressive histone methylation in the developing} corpus callosum

Myelination in developing white matter tracts in the rodent brain can be tracked by the temporal pattern of myelin gene expression and protein synthesis during the first postnatal weeks (data not shown). The detection of two repressive histone modifications, $\mathrm{H} 3 \mathrm{~K} 9 \mathrm{me} 3$ and H3K27me3, in the developing corpus callosum, within the same temporal window (data not shown) suggested the deposition of these histone marks during the transition of OPC into myelin forming cells. To validate this interpretation, we performed immunohistochemistry of postnatal brain sections from Cnp-EGFP mice (Fig. 1a), which express the reporter EGFP under the lineage-specific Cnp promoter (Yuan et al., 2002). This analysis confirmed increasing numbers of $\mathrm{H} 3 \mathrm{~K} 9 \mathrm{me} 3{ }^{+} / \mathrm{EGFP}^{+}$ cells, and to a lesser extent also of $\mathrm{H} 3 \mathrm{~K} 27 \mathrm{me}^{+} / \mathrm{EGFP}^{+}$cells, in the developing corpus callosum of the transgenic reporter mice during developmental myelination (Fig. 1b).

\section{ChIP-Seq identified unique methylation signatures in differentiating OLs}

The concomitant increase of both $\mathrm{H} 3 \mathrm{~K} 9$ and $\mathrm{H} 3 \mathrm{~K} 27$ methylation levels in white matter tracts during developmental myelination raised questions related to potential redundancy of these marks and their functional significance. One possibility was that repressive histone marks were randomly selected (i.e., either $\mathrm{H} 3 \mathrm{~K} 9 \mathrm{me} 3$ or $\mathrm{H} 3 \mathrm{~K} 27 \mathrm{me} 3$ ) to repress functionally not related genes during OPC differentiation. An alternative possibility was that H3K9me3 or H3K27me3 was selectively used by OPCs to repress functionally related gene categories. To distinguish between these possibilities and define the genome-wide distribution of these repressive marks, we performed immunoprecipitation of chromatin samples isolated from OPCs and iOLs, using antibodies specific for $\mathrm{H} 3 \mathrm{~K} 9 \mathrm{me} 3$ and $\mathrm{H} 3 \mathrm{~K} 27 \mathrm{me} 3$ followed by genome-wide deep-sequencing (ChIP-Seq). This strategy yielded $>200$ million reads per sample that were aligned to the rat genome and classi-
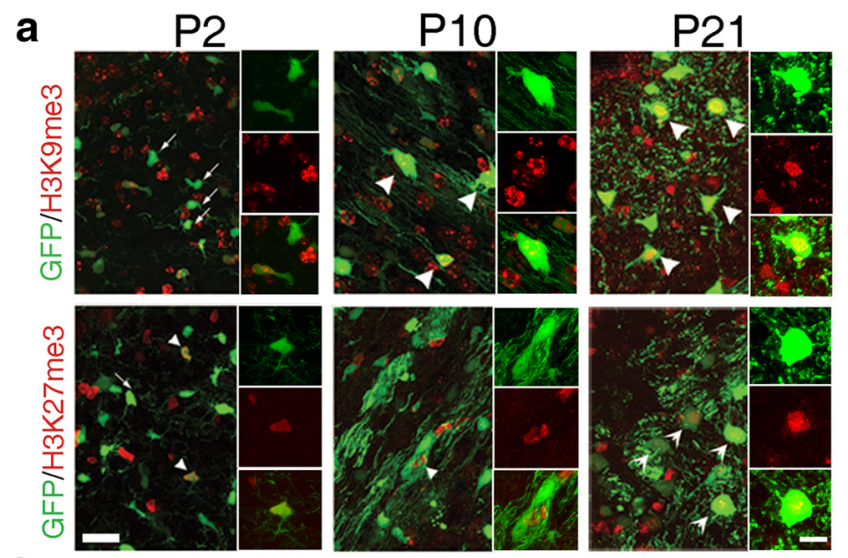

b

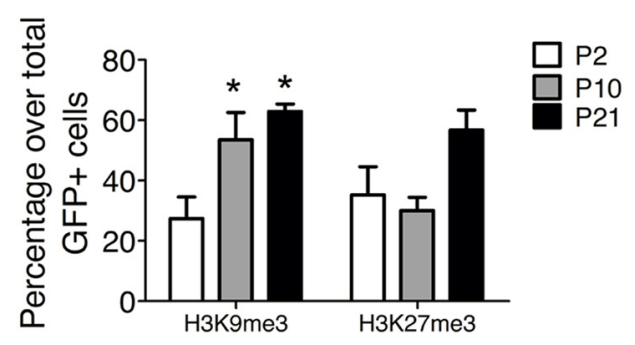

Figure 1. Increasing levels of repressive histone methylation during developmental myelination in the corpus callosum. $\boldsymbol{a}$, Representative confocal images of repressive histone marks (red) in OL lineage cells (green) in the developing corpus callosum of (np-EGFP mice. Arrows indicate GFP ${ }^{+} /$histone marks ${ }^{-}$cells. Arrowheads identify GFP ${ }^{+} /$histone marks ${ }^{+}$cells. Scale bars: low magnification, $20 \mu \mathrm{m}$; insets, $10 \mu \mathrm{m}$. $\boldsymbol{b}$, Bar graphs represent the percentage of $0 \mathrm{~L}$ lineage cells with trimethylated lysine 9 on H3 (H3K9me3) or at trimethylated lysine 27 (H3K27me3). $n=3$ animals per age from three separate litters. Data are mean \pm SEM. ${ }^{*} p<$ 0.05 (one-way ANOVA followed by Bonferroni post hoc test).

fied on the basis of enrichment regions at specific genomic locations (Zhang et al., 2008) (Fig. 2a). To identify specific gene targets regulated by $\mathrm{H} 3 \mathrm{~K} 9 \mathrm{me} 3$ and $\mathrm{H} 3 \mathrm{~K} 27 \mathrm{me} 3$, we analyzed regions of enrichment (i.e., peaks) at gene bodies and $10 \mathrm{~kb}$ regions, either upstream of the TSS or downstream from the TTS. We noticed that $\mathrm{H} 3 \mathrm{~K} 9 \mathrm{me} 3$ marks were mainly located at gene bodies, whereas $\mathrm{H} 3 \mathrm{~K} 27 \mathrm{me} 3$ were preferentially located within the $10 \mathrm{~kb}$ flanking regions (Fig. $2 b$ ). We also noticed that the overlap of genes regulated by $\mathrm{H} 3 \mathrm{~K} 27 \mathrm{me} 3$ and $\mathrm{H} 3 \mathrm{~K} 9 \mathrm{me} 3$ was greater at the progenitor stage, whereas gene repression at the $\mathrm{iOL}$ stage was mostly accounted by the H3K9me3 mark (Fig. 2b). Thus, although both serving repressive roles, $\mathrm{H} 3 \mathrm{~K} 9 \mathrm{me} 3$ and $\mathrm{H} 3 \mathrm{~K} 27 \mathrm{me} 3$ occupied distinct genomic locations at distinct stages of $\mathrm{OL}$ differentiation.

To begin unraveling the biological function of genes repressed by $\mathrm{H} 3 \mathrm{~K} 9 \mathrm{me} 3$ or $\mathrm{H} 3 \mathrm{~K} 27 \mathrm{me} 3$ marks, we filtered out potential false positives (by discarding genes characterized by the presence of single peaks) and identified 920 genes that were uniquely repressed by $\mathrm{H} 3 \mathrm{~K} 9 \mathrm{me} 3$ in OPCs and 820 genes in differentiating OLs (Fig. 2c). The H3K27me3 mark, in contrast, was uniquely detected at 653 genes in OPCs and 300 genes in iOLs (Fig. 2d). Therefore, in more differentiated iOLs, gene repression was mostly achieved by the deposition of the repressive $\mathrm{H} 3 \mathrm{~K} 9 \mathrm{me} 3$ marks. These data also suggested that the H3K27me3 mark may play a role in repression at the progenitor state, whereas the $\mathrm{H} 3 \mathrm{~K} 9 \mathrm{me} 3$ was likely to be involved in gene repression responsible for refining the functional properties of OPC as they transitioned into OL. Gene annotation, using DAVID (Fig. 2c-f), revealed distinctive ontology terms for the genes repressed by $\mathrm{H} 3 \mathrm{~K} 9 \mathrm{me} 3$ or $\mathrm{H} 3 \mathrm{~K} 27 \mathrm{me} 3$ at each differentiation stage. The 
H3K27me3 mark was identified at genomic regions containing genes regulating "global alternative lineage choice" (e.g., cell adhesion Fig. $2 d$ ) in progenitors. The H3K9me3 mark, in contrast, was identified at genes regulating the electrical properties of OPC (GO categories: "neuronal identity," "regulation of synaptic transmission," and "ion transport”). The association of $\mathrm{H} 3 \mathrm{~K} 9 \mathrm{me} 3$ mark with these repressed genes was lineage-specific as a distinct set of genes was regulated by $\mathrm{H} 3 \mathrm{~K} 9 \mathrm{me} 3$ in the neuronal lineage (Schaefer et al., 2009) (Fig. 2e,f). The overlap of the genomic distribution of $\mathrm{H} 3 \mathrm{~K} 9 \mathrm{me} 3$ and $\mathrm{H} 3 \mathrm{~K} 27 \mathrm{me} 3$ in the OL lineage was quite small, as only 43 genes were characterized by both repressive marks at the OPC stage and only 25 genes contained H3K9me3 and H3K27me3 in iOLs (Fig. 2e), These findings suggested that repressive $\mathrm{H} 3 \mathrm{~K} 9 \mathrm{me} 3$ and $\mathrm{H} 3 \mathrm{~K} 27 \mathrm{me} 3$ were not functionally equivalent or redundant during the differentiation of OPCs into OLs.

To refine this analysis, we compared our gene list with a newly published transcriptome database (Zhang et al., 2014). Of the 820 rat genes uniquely repressed by $\mathrm{H} 3 \mathrm{~K} 9 \mathrm{me} 3$ in differentiating OLs, we detected 740 mouse homologous genes in the published transcriptome. Of these 740 genes, 399 transcripts $(\sim 54 \%)$ were downregulated $>2$-fold during OPC differentiation and only 47 transcripts ( $\sim 6 \%)$ were upregulated, thereby confirming the repressive role of the deposition of $\mathrm{H} 3 \mathrm{~K} 9 \mathrm{me} 3$ marks. Gene ontology analysis of the 740 genes further revealed that $158(21 \%)$ of the H3K9me3associated genes were classified as "neuronal lineage enriched" and 128 genes $(\sim 17 \%)$ as "astrocytic lineage enriched." The remaining genes were involved in regulating alternative cell fate choice outside CNS or general transcriptional regulation. Together, these results suggested that the deposition of repressive $\mathrm{H} 3 \mathrm{~K} 9 \mathrm{me} 3$ marks in the chromatin of $\mathrm{iOL}$ is associated with transcriptional repression.

To best illustrate the differences between the distribution of $\mathrm{H} 3 \mathrm{~K} 9 \mathrm{me} 3$ and $\mathrm{H} 3 \mathrm{~K} 27 \mathrm{me} 3$ in OPCs and iOLs, we used IGV (Fig. 3a). This visualization tool allowed to better appreciate the relative stable genomic location of the $\mathrm{H} 3 \mathrm{~K} 27 \mathrm{me} 3$ mark at the two stages of OL lineage differentiation, and the dynamic increase of $\mathrm{H} 3 \mathrm{~K} 9 \mathrm{me} 3$ repressive marks as OPCs differentiated into OLs. The increased deposition of $\mathrm{H} 3 \mathrm{~K} 9 \mathrm{me} 3$ marks was detected at target genes encoding for transcription factors (i.e., $L h x 1$ and $P a x 9$ ), glutamatergic signaling molecules (i.e., Grip1), and a
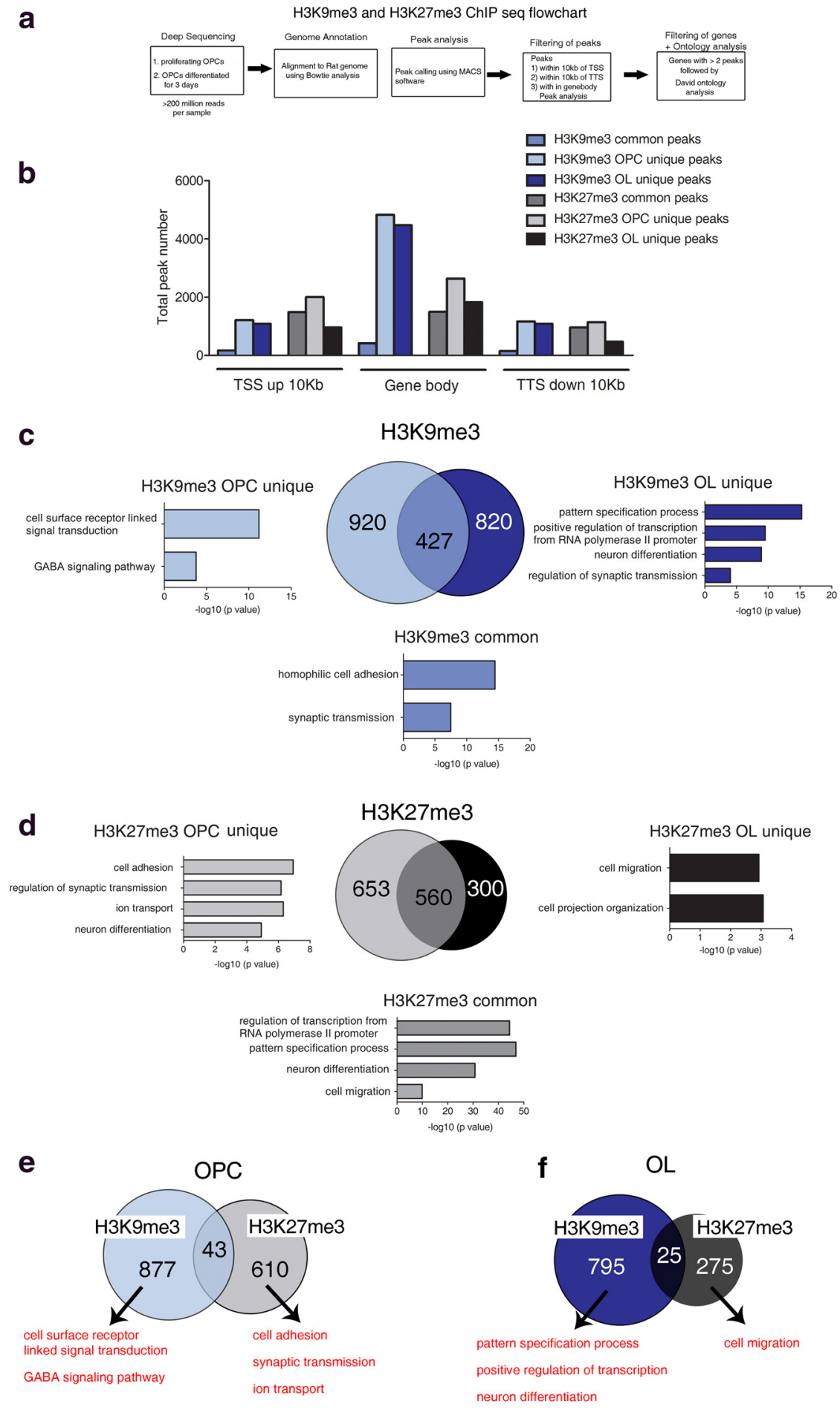

regulation of synaptic transmission

Figure 2. Genome-wide analysis of distributions of the repressive marks $\mathrm{H} 3 \mathrm{~K} 9 \mathrm{me} 3$ and H3K27me3 during OPC differentiation. $\boldsymbol{a}$, Flow chart depicting the methods of analysis of the ChIP-seq data. $\boldsymbol{b}$, Bar graph represents the overall genomic distribution of the repressive H3K9me3 and H3K27me3 peaks in progenitors (OPCS) and in differentiating $0 \mathrm{Ls}$ after filtration of peaks in the intergenic region. Note the stability of the H3K27me3 marks between OPCs and OLs throughout the genome and the differential distribution of H3K27me3 peaks predominantly in gene regulatory regions (upstream $10 \mathrm{~kb}$ and downstream $10 \mathrm{~kb}$ ), and of $\mathrm{H} 3 \mathrm{~K} 9 \mathrm{me} 3$ peaks predominantly in the gene body. $\boldsymbol{c}, \boldsymbol{d}$, Venn diagrams represent the number of genes uniquely characterized by either $\mathrm{H3K}$ me3 (c) or H3K27me3 (d) in OPCs or OLs. Overlap indicates genes with the same methylation marks at the two developmental stages. The biological function of genes in each category was analyzed using DAVID software. Bar graphs represent the most significant ontology term clusters and are plotted based on their $p$ value. Only the ontologyterms with a $p$ value $<10^{-3}$ are shown. $\boldsymbol{e}, \boldsymbol{f}$, Venn diagrams represent thenumber and the main biological functions (red) of genes characterized by unique H3K9me3 or H3K27me3 histone marks in OPCs $(\boldsymbol{e})$ or in differentiating $0 \mathrm{Ls}(\boldsymbol{f})$. The biological function of genes in each category was analyzed using DAVID software. Representative genes were listed. Only the ontology terms that have a $p$ value $<0.005$ were shown. 

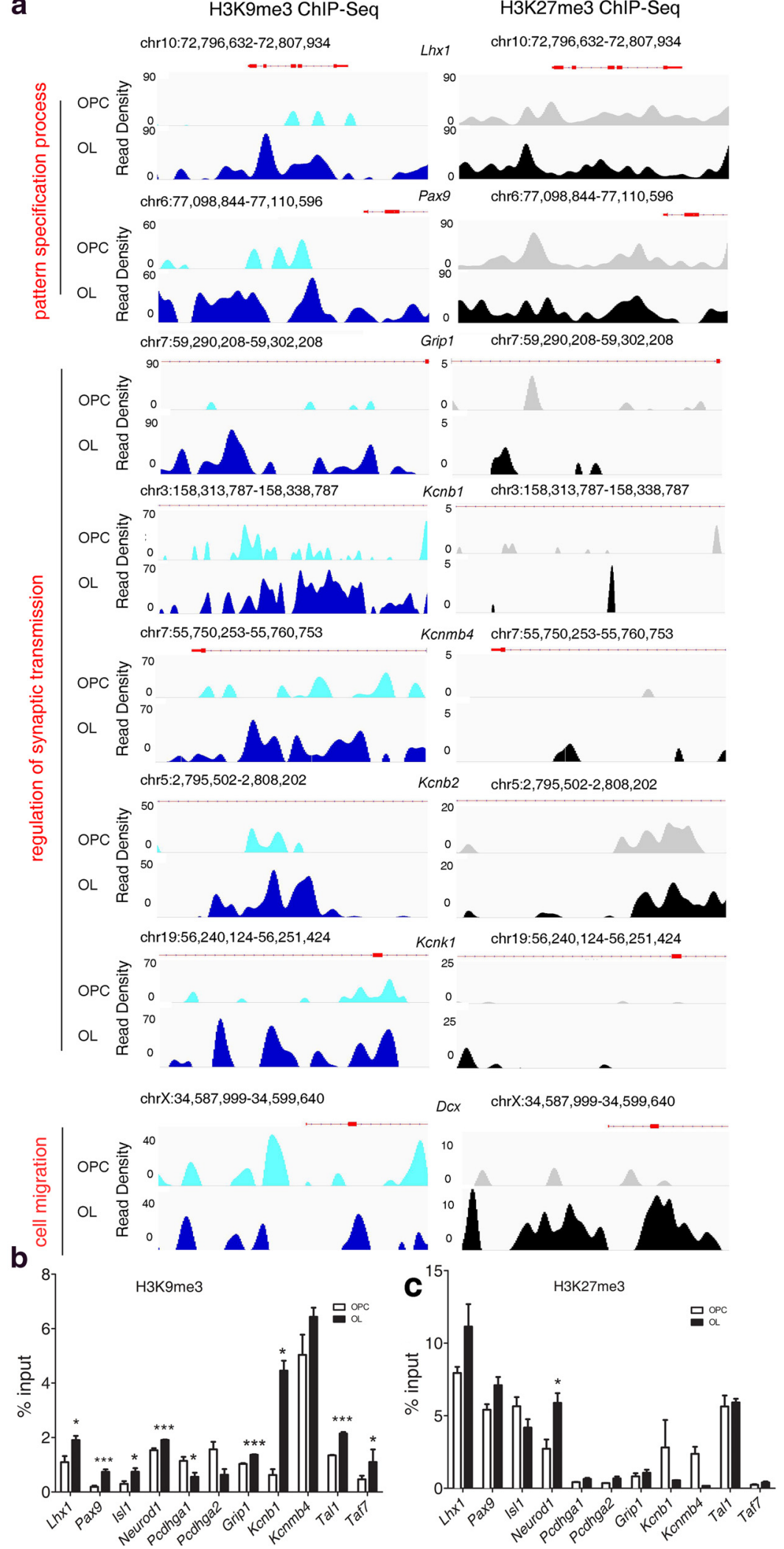

Figure 3. Visualization and validation of the ChIP-seq data. $\boldsymbol{a}$, Visualization of the H3K9me3 and H3K27me3 ChIP-Seq data obtained from progenitors (OPCS) and differentiating $0 \mathrm{Ls}$, using IGV, after input subtraction using previously described methods (Kharchenko et al., 2008). The genomic location for each gene is displayed above the peak density plots. The enriched peaks are shown by read density displayed on the $y$-axis. Thick red boxes on the Ref-seq genes represent exons. Thin lines indicate introns. The ontology term identified by DAVID analysis is shown on the left. Validation of the H3K9me3 (b) and H3K27me3 (c) ChIP-seq identified gene regions using chromatin isolated from progenitors and differentiating $0 \mathrm{Ls}$. Bar graphs represent the relative enrichment for the repressive mark for each of the indicated genes. Data are mean \pm SEM from three independent experiments. ${ }^{*} p<0.05$ (unpaired $t$ test). ${ }^{* * *} p<0.001$ (unpaired $t$ test). ion channels (i.e., Kcnb1, Kcnb2, Kcnk1, and Kcnmb4). An exception to this rule was the regulation of a gene involved in neuronal migration (i.e., $D c x$ ), which showed increased H3K27me3 as OPC differentiated (Fig. 3a). These findings were independently validated on 11 distinct target genes, by using quantitative ChIP and primers corresponding to the genomic coordinates visualized by IGV (Fig. 3b,c). Thus, the transitional chromatin landscape from OPCs to iOLs was characterized by the gressive increase of repressive $\mathrm{H} 3 \mathrm{~K} 9 \mathrm{me} 3$ marks on genes controlling neuronal identity and membrane excitability.

\section{Expression pattern and enzymatic activity of $\mathrm{H} 3 \mathrm{~K} 9$ and H3K27 HMTs in the developing forebrain}

To identify the enzymatic activities responsible for increased methylation on distinct lysine residues of histone $\mathrm{H} 3$ during myelination, we FACS-sorted OL lineage cells from transgenic Cnp-EGFP mouse brains at multiple postnatal developmental time points. Background fluorescence was set from cell suspensions prepared from nontransgenic littermates (Fig. 4a), and the fluorescence selection criteria were validated by the antigenic characterization of the cell preparation (data not shown) and by measuring the transcript levels of myelin genes by qPCR (Fig. $4 b$ ). Consistent with the progression along the lineage, the relative proportion of $\mathrm{O}^{+}$cells (data not shown), the transcript levels of myelin gene (i.e., Cnp, $M b p$, and Mag), and the OL-specific transcription factor Sox10 significantly increased over time (Fig. 4b). Of the family of K9 HMTs (H3K9 HMTs), three of four family members were expressed at high levels (Fig. 4c,d): Ehmt2 (also known as G9a), Ehmtl (also known as Glp), and Suv39h1, thereby suggesting functional redundancy. The expression pattern and levels of the H3K27 HMT Ezh2 were lower but also expressed in differentiating OPCs (Fig. 4c).

Next, we asked whether the enzymatic activities of the H3K9 HMTs andH3K27 HMT were similarly modulated by exposure to signals that favor (i.e., thyroid hormone) or prevent (i.e., BMP4) OL differentiation (Wu et al., 2012). Consistent with a prominent role of $\mathrm{H} 3 \mathrm{~K} 9 \mathrm{me} 3$ during OL differentiation, thyroid hormone treatment induced an eightfold increase of H3K9 HMT activity and a twofold increase of H3K27 HMT, whereas BMP4 did not significantly alter the activity of these enzymes (Fig. 4e). 
a

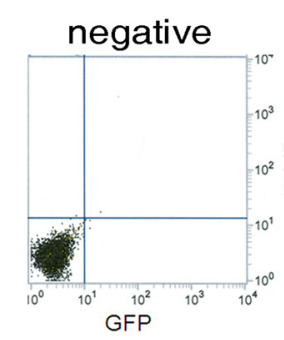

C

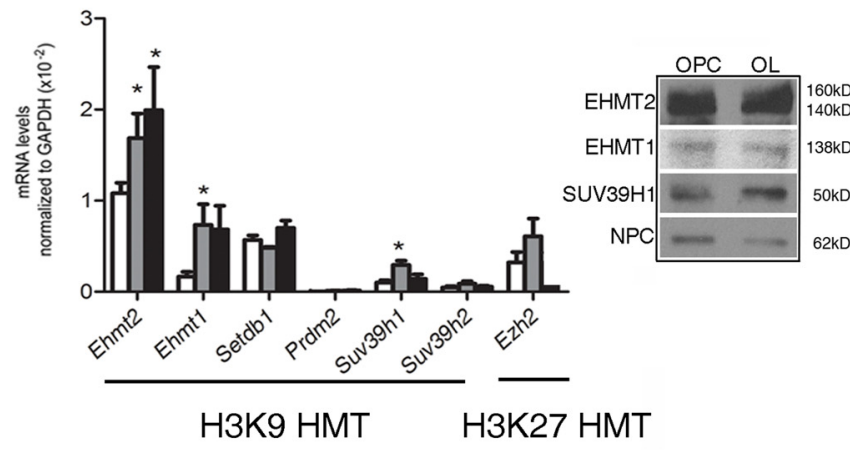

b

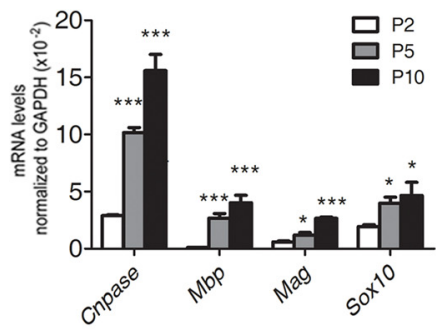

e
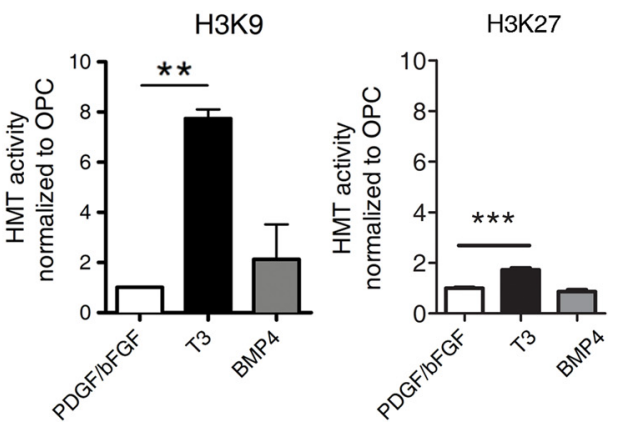

Figure 4. Expression levels and enzymatic activity of K9 HMT activity in OL lineage cells are increased by differentiation stimuli. $a$, FACS analysis dot plot of EGFP fluorescence ( $y$-axis; logarithmic scale) of brain cell suspension from CNP-EGFP mice (sample). Littermates were used as negative controls to set up gating parameters. $\boldsymbol{b}, \mathrm{OL}$-specific transcript levels measured in cells after sorting at the indicated developmental time points, using real-time qPCR. $\boldsymbol{c}$, Transcript levels of specific H3K9 and H3K27 HMTs in the same population of cells as panel $\boldsymbol{b}$ after sorting. $n=3$ separate litters per time point. ${ }^{*} p<0.05$ (one-way ANOVA followed by unpaired $t$ test). ${ }^{* *} p<0.01$ (one-way ANOVA followed by unpaired $t$ test). ${ }^{* * *} p<0.005$ (one-way ANOVA followed by unpaired $t$ test). $\boldsymbol{d}$, Representative Western blots showing expression of HMTs using nuclear extracts from primary OL cultures. $\boldsymbol{e}$, H3K9 and H3K27 methyltransferase activity specifically increased when OPCs were differentiated into $0 \mathrm{Ls}$ using thyroid hormone (T3), but not astrocytes using BMP4. The increase of H3K27 methyltransferase activity was to a much less extent than H3K9 methyltransferases when OPCs were treated with T3. $n=3$ separate cultures per condition. ${ }^{* *} p<0.01$ (one-way ANOVA). ${ }^{* *} p<0.005$ (one-way ANOVA). Data are mean \pm SEM.

\section{Inhibition of H3K9 methylation, but not $\mathrm{H} 3 \mathrm{~K} 27$ methylation, impaired differentiation of cultured OPC and myelination of central axons}

The detection of histone methylation in differentiating OLs did not allow us to determine whether it was necessary for differentiation or the consequence of the differentiation process. To begin unraveling this question, we first adopted a pharmacological approach using enzymatic inhibitors of H3K9 HMT (i.e., Bix 1294, as described by Kubicek et al., 2007) or H3K27 HMT (i.e., GSK126, as described by McCabe et al., 2012). A dose-response of toxicity was performed in primary cells using an MTT assay (data not shown) and effectiveness at nontoxic doses was evaluated by Western blot analysis of $\mathrm{H} 3 \mathrm{~K} 9 \mathrm{me} 3$ and $\mathrm{H} 3 \mathrm{~K} 27 \mathrm{me} 3$ levels before and after treatment (Fig. 5a,c). Treatment of OPCs with nontoxic doses of Bix or GSK126 throughout differentiation revealed decreased myelin gene transcripts (i.e., Mag and Cnp) only in cells treated with the H3K9 HMT inhibitor (Fig. 5b), and not in those treated with the H3K27me3 inhibitor (Fig. $5 d$ ). Together, these results reinforced the concept that differentiation of OPC into OL requires $\mathrm{H} 3 \mathrm{~K} 9 \mathrm{HMT}$ activity.

To further test this hypothesis, we adopted a silencing approach using lentiviral vectors, each containing a specific short hairpin RNA (shRNA), the EGFP as reporter to evaluate transduction efficiency and a puromycin selection marker. The transduction efficiency in primary cultures was consistent throughout multiple experiments and ranged between $45 \%$ and 50\% (data not shown). Silencing efficiency, measured by transcript and protein levels, was calculated to be $50 \%$ (data not shown) and lack of off-target effects was further assessed by measuring transcript and protein levels of every member of the H3K9 HMT family after silencing each one of them (data not shown). To distinguish between the possibilities of $\mathrm{H} 3 \mathrm{~K} 9 \mathrm{me} 3$ marks as important for the induction of OL differentiation or for the maintenance of the OL differentiated state, we performed silencing at two stages of differentiation. First, we silenced H3K9 HMT in proliferating progenitors, selected them in puromycin, and then allowed them to differentiate in the presence of thyroid hormone for $4 \mathrm{~d}$ (Fig. $5 e$ ). Cultures transduced with lentiviral vectors containing the EGFP reporter, the puromycin selection markers, and a scrambled ShRNA sequence were used as controls. Toxicity was evaluated by visual inspection of EGFP fluorescence and lack of immunoreactivity for antibodies specific for the active form of caspase 3 (data not shown). Differentiation was assessed by immunocytochemistry using $\mathrm{O} 1$ antibodies to identify mature OLs (Fig. $5 f$ ) and revealed fewer $\mathrm{Ol}^{+}$cells and lower myelin gene transcripts in cultures after silencing of the H3K9 HMT Ehmt2, and/or Suv39h1, but not of the H3K27 HMT Ezh2 (Fig. 5f). In a second set of experiments, silencing was performed in cells already differentiated into OLs, by T3 treatment (Fig. $5 g$ ). Also in this case, differentiation was assessed by immunoreactivity for antibodies specific for $\mathrm{O} 1$ (Fig. $5 g$ ), which did not reveal any difference between silenced or nonsilenced cells (Fig. 5h). Together, these data suggest that the activity of the H3K9 HMT (but not of H3K27 HMT) is induced by thyroid hormone and is required for the first stages of OPC differentiation into OL, although it is dispensable for maintenance of the mature OL state.

To further validate the effect of the H3K9 HMT inhibitor Bix on myelination of CNS axons, we repeated the experiments in cortical and cerebellar organotypic slice cultures, which provide 

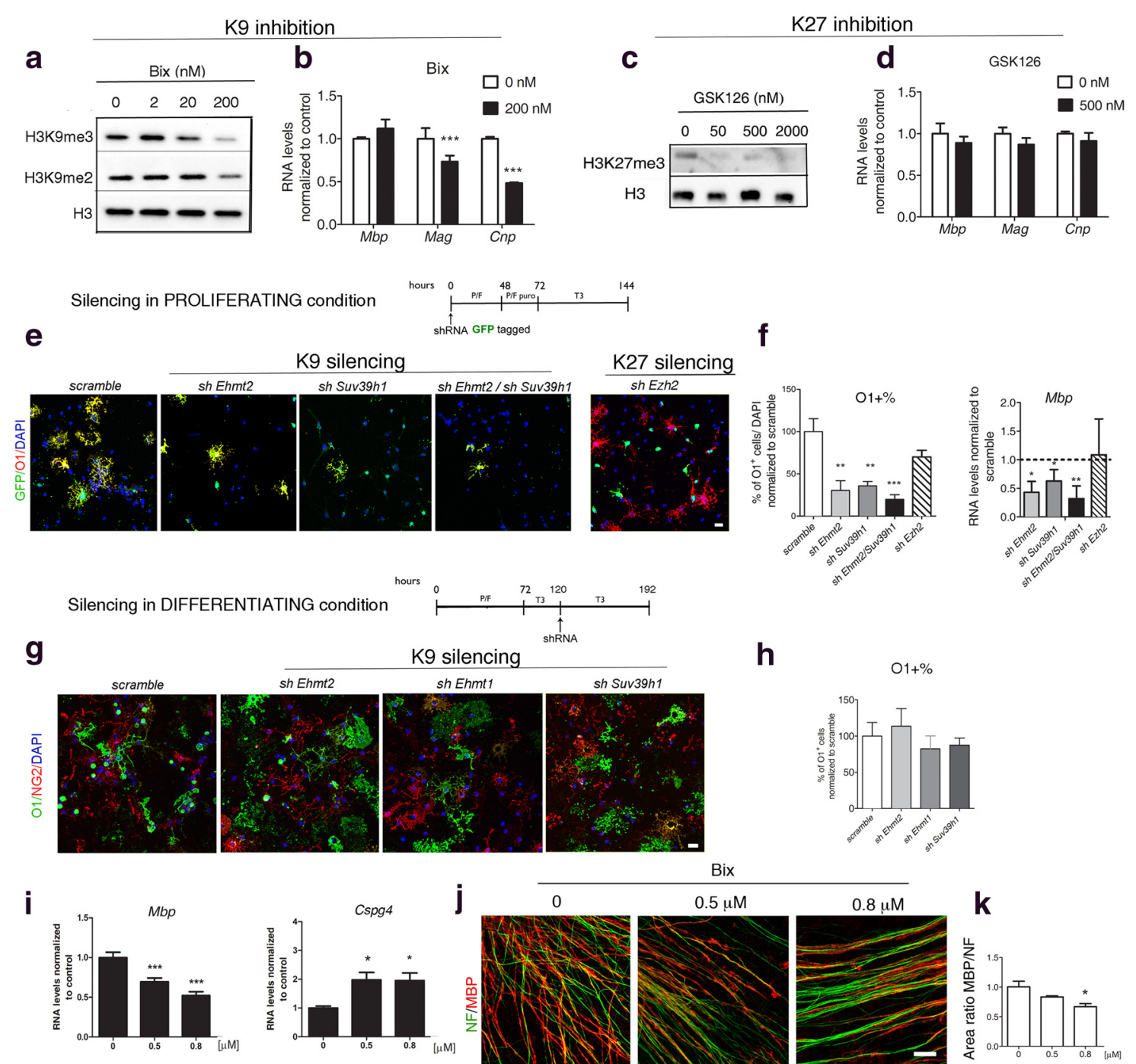

K9 silencing

ShRNA
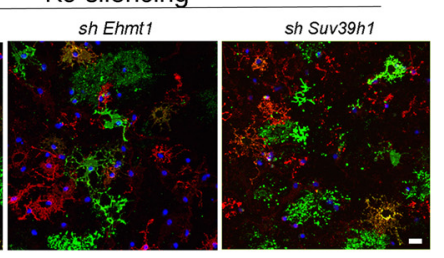

h
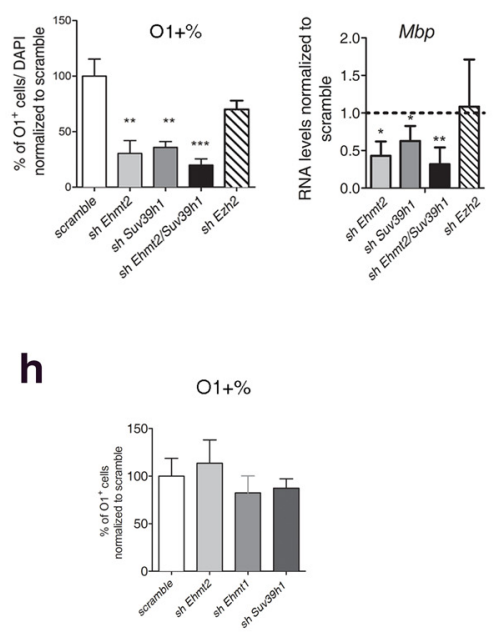

Bix
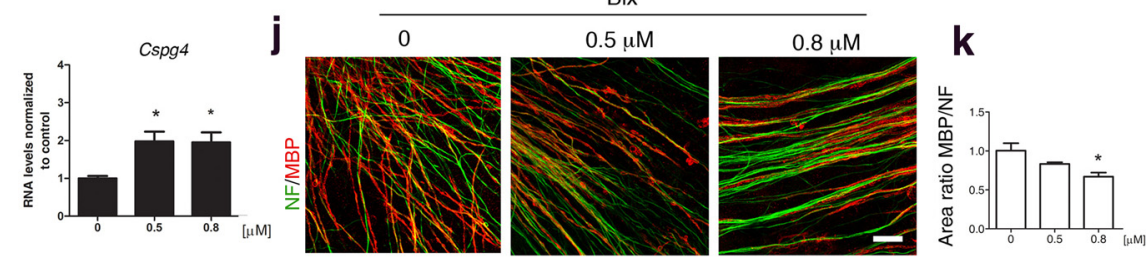

Figure 5. Inhibition of $\mathrm{H} 3 \mathrm{~K} 9$, but not H3K27, methylation prevented differentiation of cultured OPCS and myelination of central axons. Dose-dependent inhibition of H3K9 or H3K27 methyltransferase activity was validated by Western blot analysis of histone extracts from cultured OPCs treated with the indicated doses of Bix and probed with antibodies specific for H3K9me3 and H3K9me2 (a) or with antibodies specific for H3K27me3 (c). Transcript levels of myelin genes (i.e., Mbp, Mag, and Cnp) were measured in OPCs cultured for $4 \mathrm{~d}$ in differentiation medium with the indicated doses of Bix (b) or GSK126(d). ${ }^{* * *} p<0.001$ (one-way ANOVA test from three separate cultures). $\boldsymbol{e}$, Schematics of the experimental paradigm used to silence proliferating OPCs. Cells were kept in the presence of mitogen, PDGF-AA, and bFGF (P/F) for $72 \mathrm{~h}$ before differentiating with T3. Representative confocal images of primary OPC cultures that were transduced with GFP-tagged lentiviral shRNAs specific for the indicated H3K9 and H3K27 methyltransferases, then differentiated for $4 \mathrm{~d}$, and stained for markers specific for mature $0 \mathrm{Ls}(01)$ (red). Scale bar, $20 \mu \mathrm{m}$. $\boldsymbol{f}$, The number of $01^{+} \mathrm{OLS}$ was calculated and referred to as percentage of the total number of DAPI ${ }^{+}$cells and then normalized to scramble control. The transcript levels (bar graphs) of Mbp during $0 \mathrm{~L}$ differentiation were measured by qRT-PCR in each silencing condition and then normalized to an internal reference gene (Gapdh) and referred to as fold changes from the levels detected in scrambled shRNA controls (line). ${ }^{*} p<0.05 .{ }^{* *} p<0.005 .{ }^{* *} p<0.001$ (one-way ANOVA test from four independent cultures). $\boldsymbol{g}$, Schematics of the experimental paradigm used to silence differentiating $0 \mathrm{Ls}$. Representative confocal images of primary OPC cultures transduced with lentiviral shRNA specific for the indicated H3K9 methyltransferases under differentiating conditions and then stained for 0Ls (01) (green) markers. Scale bar, $20 \mu \mathrm{m} . \boldsymbol{h}$, The percentage of $01^{+} \mathrm{OLs} / \mathrm{DAPI}^{+}$was calculated and normalized to control. $\boldsymbol{i}$, Transcript levels of Mbp and Cspg4, which encodes for NG2, measured in cerebellar slice culture treated with the indicated doses of Bix for $12 \mathrm{~d}$. Untreated slice cultures served as controls. All the transcript values were normalized to RplpO as internal control.j, Immunohistochemistry of MBP (red) and neurofilament (NF, $\mathrm{green}$ ) in Bix-treated cerebellar slices allowed the identification of myelinated fibers. Scale bar, $20 \mu \mathrm{m}$. $\boldsymbol{k}$, Quantification of the intensity ratio of MBP/NF in Bix-treated slice cultures revealed a dose-dependent decrease in Bix-treated cultures. ${ }^{*} p<0.05$ (one-way ANOVA test from three independent cultures). ${ }^{* *} p<0.01$ (one-way ANOVA test from three independent cultures). ${ }^{* * *} p<0.005$ (one-way ANOVA test from three independent cultures). Data are mean \pm SEM.

an elegant ex vivo experimental system retaining the cytoarchitecture of the tissue of origin. A dose-response of toxicity was generated by assessing apoptotic cells by TUNEL (data not shown), and nontoxic doses were selected for long-term treatment and analysis of myelination. Consistent with the results in cortical OPC cultures, Bix treatment of both cortical (data not shown) and cerebellar slice cultures resulted in a dosedependent decrease of myelin gene transcripts $(M b p)$ (Fig. $5 i$ ) and fewer myelinated fibers (Fig. 5j,k). The impaired differentiation of OPC into myelinating OL in Bix-treated slice cultures was further supported by the concomitant detection of higher transcripts for OPC markers (i.e., Cspg4, also known as NG2) (Fig. 5i), in the absence of any effect on the expression of neuronal markers (i.e., $R b$ fox3, also known as $\mathrm{NeuN}$ ) (data not shown).

Transcriptional changes induced by knockdown of H3K9 methyltransferase induced alteration of membrane excitability in OL lineage cells

To understand the functional consequences of deposition of repressive $\mathrm{H} 3 \mathrm{~K} 9 \mathrm{me} 3$ and $\mathrm{H} 3 \mathrm{~K} 27 \mathrm{me} 3$ marks during OL lineage 
a

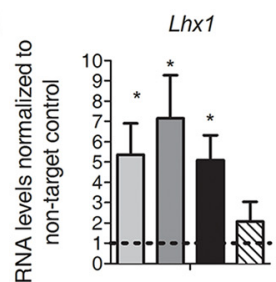

scramble

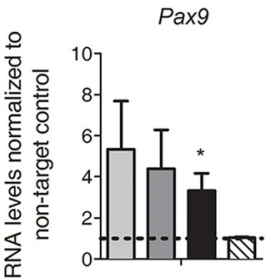

sh Ehmt2

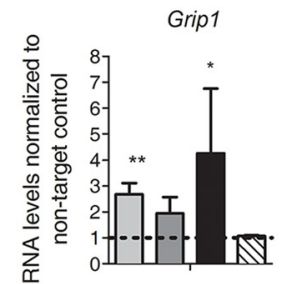

sh Suv39h1
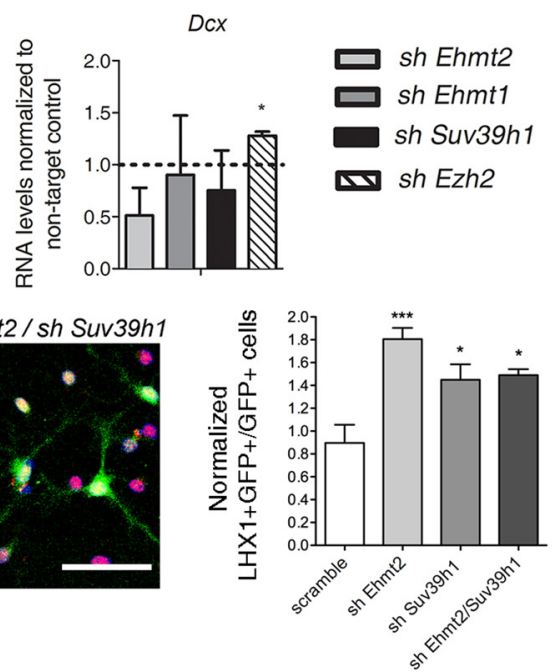

C
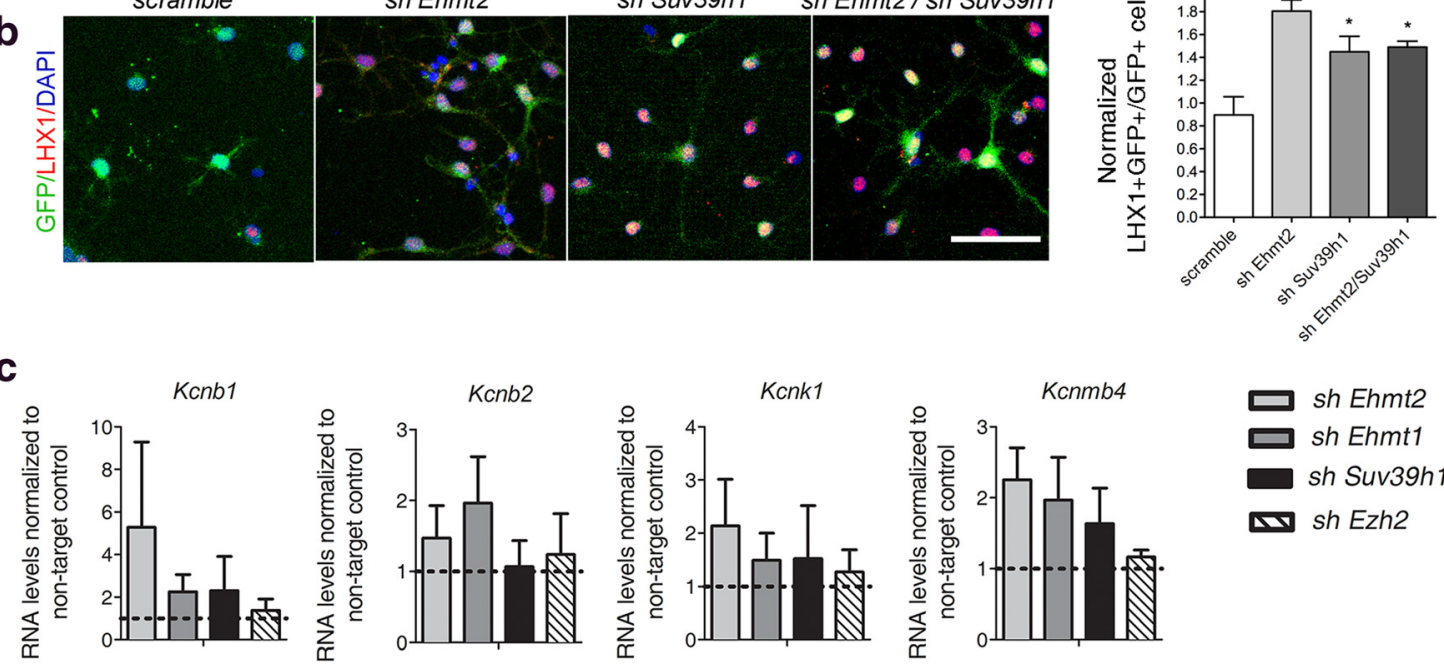

d

e
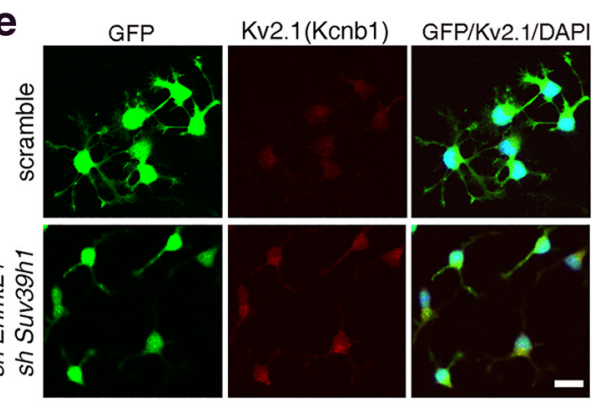

f
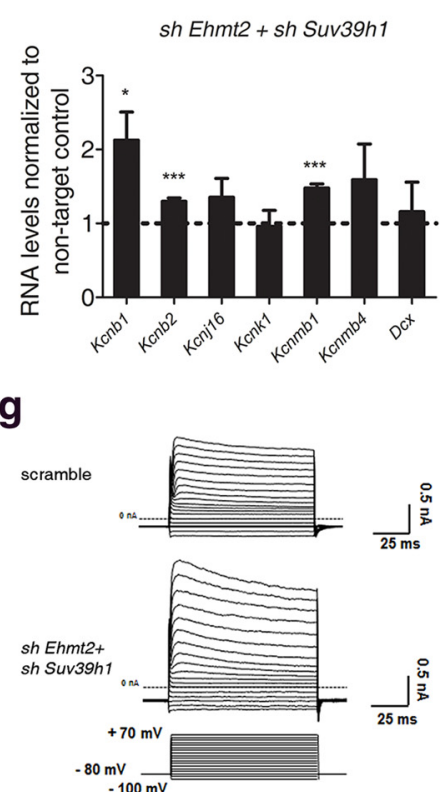

h

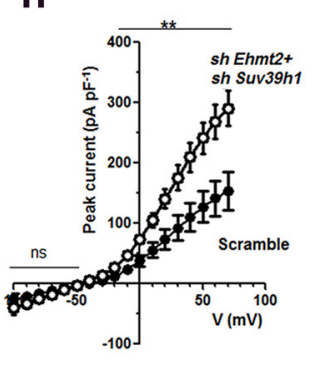

i

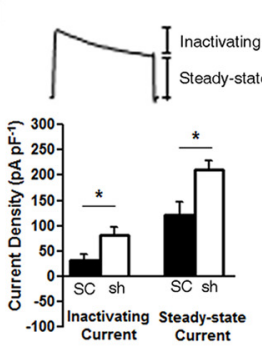

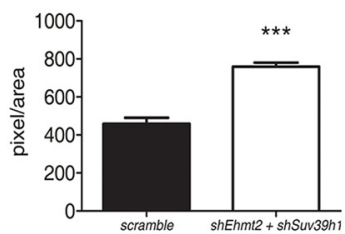

j

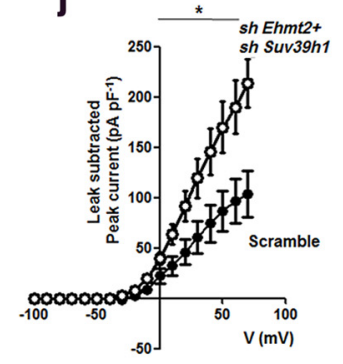

Figure 6. Silencing specific $\mathrm{H3} 39$ methyltransferases, but not $\mathrm{H} 3 \mathrm{~K} 27 \mathrm{HMTs}$, resulted in aberrant expression of neuronal genes and enhanced excitability in immature $0 \mathrm{Ls}$. $\boldsymbol{a}$, The transcript levels of neuronal lineage genes were measured by qRT-PCR in primary OPCs silenced with constructs specific for indicated H3K9 or H3K27 methyltransferases and then differentiated for $4 \mathrm{~d}$. RNA levels were normalized to an internal reference gene (Gapdh) and then referred as fold changes of the levels detected in scrambled shRNA controls (line). ${ }^{*} p<0.05$. ${ }^{* *} p<0.005$ (one-way ANOVA test from four independent cultures). Note the specific increase of transcript level of genes characterized by unique H3K9me3 repressive marks (Lhx1, Pax9, Grip 1), occurring only in H3K9 HMT (Ehmt2, Ehmt1, Suv39h1) silenced cultures, and the increased transcript levels of genes characterized by unique H3K27me3 repressive marks (Dcx) only in H3K27 HMT (Ezh2) silenced cultures. $\boldsymbol{b}$, Representative confocal images of primary cultures transduced with indicated lentiviral shRNA and stained with antibodies specific for the neuronal marker LHX1. Bar graph represents the fold change of percentage of $\mathrm{LHX} 1^{+} \mathrm{GFP}^{+}$over the GFP ${ }^{+}$cells normalized to scrambled control. Data are mean \pm SEM from three separate cultures. ${ }^{*} p<0.05$. Scale bar, $20 \mu \mathrm{m}$. c, The transcript levels of potassium subunits were measured by qRT-PCR in the experimental paradigm and calculated as described in $\boldsymbol{a} . n=4$ independent cultures. $\boldsymbol{d}$, The transcript levels of potassium channel subunits in OPCs differentiated for $4 \mathrm{~d}$ were measured by qRT-PCR in each cultures infected with lentivirus encoding for shRNA against Ehmt2 and shRNA against Suv39h 1 and then calculated as described in a. Transcripts of a H3K27me3 target gene, $D C x$, were not affected. ${ }^{*} p<0.05 .{ }^{* * *} p<0.001$ (one-way ANOVA test from four independent cultures). $\boldsymbol{e}$, Representative confocal images of immunocytochemistry of Kv2.1 subunits on cells infected with scramble control and Ehmt2 and Suv39h1 shRNA lentiviruses. $f$, Pixel intensity was quantified by Image software ( $n \geq 70$ cells per condition from two separate cultures, $p<0.05$ by unpaired $t$ test). Scale bar, $20 \mu \mathrm{m} . \boldsymbol{g}$, Voltage-dependent outward currents elicited from scramble (top) or shEhmt2 + shSuv39h1 (middle) cells at $10 \mathrm{mV}$ intervals using the pulse protocol shown (bottom). $\boldsymbol{h}$, Quantified peak current density plotted against voltage $(\mathrm{mV})$ demonstrating larger outward currents elicited from shEhmt2 + shSuv39h 1 (open circles) compared with scramble (closed circles). $\boldsymbol{i}$, Current density plotted with respect to inactivating (left) or steady-state currents (right) in each group, (Figure legend continues.) 
identity acquisition, we measured genes involved in neuronal lineage, synaptic transmission, and ion transport in primary OPC cultures after silencing H3K9 HMT (Ehmt1, Ehmt2, Suv39h1) or H3K27 HMT (Ezh2). In agreement with the initial identification of Lhx1, Pax9, and Grip1 as H3K9me3 target genes, their transcripts were higher in K9HMT-silenced cultures than in control or in Ezh2-silenced cultures (Fig. 6a). Conversely, the levels of the H3K27me3 target gene Dcx were unaffected by H3K9 HMTsilencing but upregulated in Ezh2-silenced cultures (Fig. 6a). The transcriptional increase of $L h x 1$ was also reflected in a higher proportion of $\mathrm{LHX}^{+}{ }^{+}$cells in cultured OPCs after silencing of the H3K9 HMTs, Ehmt2, Suv39h1, or both, compared with control cultures with similar levels of transduction efficiency (Fig. 6b). These results supported the different function of $\mathrm{H} 3 \mathrm{~K} 9 \mathrm{me} 3$ and H3K27me3 marks in restricting lineage-specific genes and also indicated the functional redundancy of H3K9 HMTS, which precluded the assessment of biological function using a single knockout transgenic approach.

Given that the most significant gene ontology categories were related to regulation of synaptic transmission and ion transport, we then asked whether gene expression changes caused by $\mathrm{H} 3 \mathrm{~K} 9 \mathrm{me} 3$ deposition would bear functional consequence on the electric properties of silenced OPCs. Because genes encoding for potassium channel subunits composed the largest category in the synaptic transmission and ion transport ontology, and given the fact that downregulation of potassium channel transcripts was previously detected during the OPC to OL transition (Cahoy et al., 2008), we asked whether silencing OPCs resulted in changes in potassium channel expression. Silencing individual H3K9 HMT resulted in a trend toward increased transcript levels for four potassium subunits, but the data lacked statistical significance, possibly due to some levels of compensation from other H3K9 HMTs (Fig. 6c). However, silencing of two distinct H3K9 HMTs (i.e., Ehmt2 and Suv39h1) resulted in statistically significant increased transcripts for Kcnb1 (Kv2.1), Kcnb2 and Kcmb1 (Fig. $6 d$ ), and increased expression of Kv2.1 protein detected by immunocytochemistry (Fig. 6e,f). To further explore the increase in potassium channel expression, we performed whole-cell patch-clamp recordings in transduced progenitors that were allowed to differentiate in chemically defined medium. We first examined total inward and outward current and found that the amplitude of a voltage-gated outward current (peak current density) was significantly larger in cells infected with shEhmt2 and shSuv39h1 viruses, compared with control iOLs infected with scrambled shRNA (Fig. $6 g, h$ ). By contrast, there was no significant difference in the inward current densities between shEhmt2 and $\operatorname{shSuv39h1}(n=11)$ and scrambled $(n=9)$. We divided the outward current into two components: an inactivating current (peak - steady-state) and steady-state current. Both components of current were larger in cells infected with shEhmt2 and shSuv39h1 viruses (Fig. 6i,j), suggesting an effect on multiple types of potassium channels. Subtracting basal leak current revealed a current-voltage profile similar to that of Kv2 channels. Therefore, we attribute the difference in the excitability of scram-

\section{$\leftarrow$}

(Figure legend continued.) measured at the regions depicted on the representative trace (inset). SC, Scrambled; sh, shEhmt2+shSuv39h1. j, Post hoc leak subtraction of peak current density plotted against voltage $(\mathrm{mV})$ demonstrating that voltage-dependent currents are not the result of leak conductances. Knockdown of Ehmt2 + Suv39h1 resulted in larger steady-state and inactivating currents (both measured at $70 \mathrm{mV}$ ), with no effect on peak inward current measured at $-100 \mathrm{mV}$. Data are mean $\pm \operatorname{SEM}(n=9$ for scramble vs $n=11$ for shRNA from three independent cultures). ${ }^{*} p<0.05 .{ }^{* *} p<0.01$ (unpaired Student's $t$ test). bled versus H3K9 HMT silenced cells to changes in gene expression mediated by H3K9 methylation signature alteration on potassium channels.

\section{Repressive protein complexes containing repressive HMTs and OL-specific transcription factor}

The above experimental evidence clearly indicated the coordinated repression of functionally related genes by the histone mark $\mathrm{H} 3 \mathrm{~K} 9 \mathrm{me} 3$ during the transition from OPCs to OLs and raised the question related to the identification of the transcription factors bound to H3K9 HMTs. To answer this question, we conducted a MEME-ChIP analysis on the large genomic dataset generated by the ChIP-Seq data of H3K9me3 marks. We focused on the identification of DNA cis-elements associated with repressive peaks uniquely present in $\mathrm{iOL}$ and identified the presence of conserved binding motifs for the transcription factors, including YY1, REST, and SOX10 (Fig. 7a). We therefore asked whether these transcription factors formed protein complexes with $\mathrm{H} 3 \mathrm{~K} 9$ HMTs (e.g., EHMT2 and EHMT1), H3K27 HMT (EZH2), and other repressive enzymes, such as histone deacetylases (e.g., HDAC1) and DNA methyltransferases (e.g., DNMT1). The results of coimmunoprecipitation of protein extracts revealed a core complex of repressive enzymes (i.e., EHMT2, EHMT1, EZH2, CoREST, DNMT1, and HDAC1) throughout the stages of OL differentiation. Interestingly, this core complex bound to different transcription factors, depending on the stage of differentiation, with SOX10 binding in OPC and YY1 binding in OL (Fig. $7 b$ ). These data suggested a model, in which SOX10 recruited repressive complexes to target genes only in OPCs whereas YY1 recruited such complexes to additional target genes at later stages of OL development.

To further test this hypothesis, we first determined the location of the consensus sequences for the identified transcription factors (SOX10 and YY1) within the genomic regulatory regions of the target genes (Fig. 7c) and then examined occupancy at target loci, using ChIP. In agreement with the stage-specific recruitment of repressive complexes by specific transcription factors, we detected greater binding of SOX10 to its consensus sequence in the Kcnb1 gene at the OPC stage and greater YY1 binding to its consensus sequence at later stages of OL development (Fig. 7c). The colocalization of H3K9me3 histone marks and not of H3K27me3 around the binding sites of YY1 and Sox 10 further supported the concept that H3K9 HMT bind to these transcription factors at specific stages of OL development (Fig. $7 c$ ). A similar mechanism was detected at genomic locations containing the neuronal specific gene $L h x l$ (Fig. $7 c$ ). Also in this case, the binding of SOX10 at the OPC stage and the enhanced recruitment of YY1 at OL stage were observed in regions with enriched H3K9me3 marks in OLs (Fig. 7c).

Together, these data suggest a model, in which stage-specific OL transcription factors recruit repressive complexes to target genes, thereby allowing transcriptional changes eventually leading to differentiation.

\section{Discussion}

While all the cells of an organism share the same DNA, a lineagespecific transcriptional program needs to be activated to define cell diversity. We asked this question in the OL lineage, which represents one of the last cell types to differentiate during brain development. Although several studies have characterized the molecular events occurring in the initiation stage of OPC differentiation to activate the lineage progression program (Bujalka et al., 2013; Yu et al., 2013), the precise molecular mechanisms de- 
a

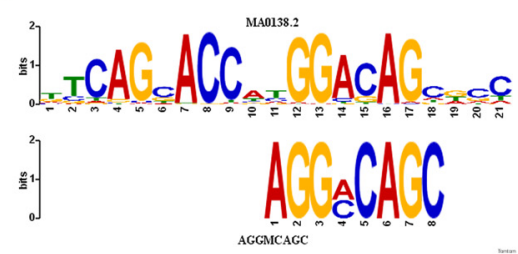

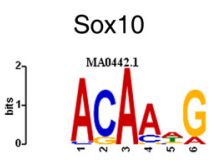

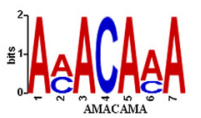

C

b

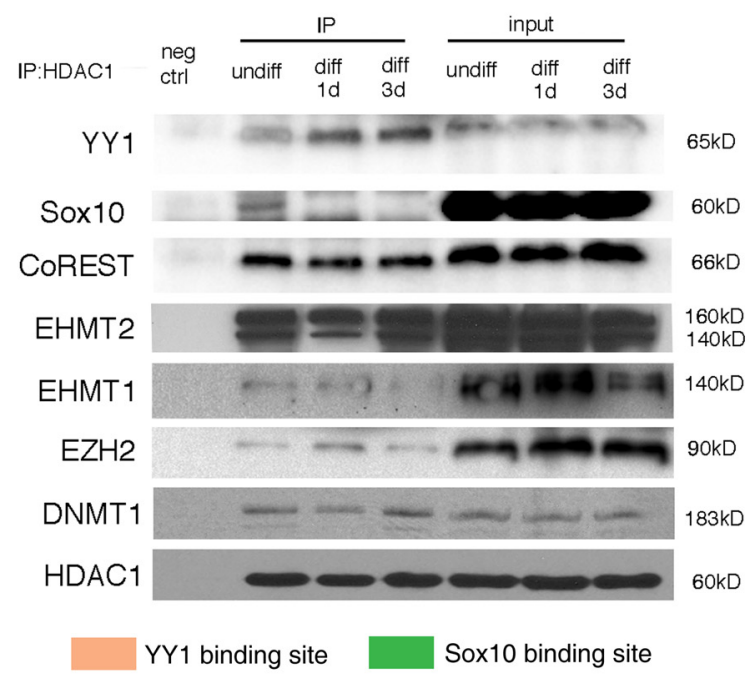

Konb1
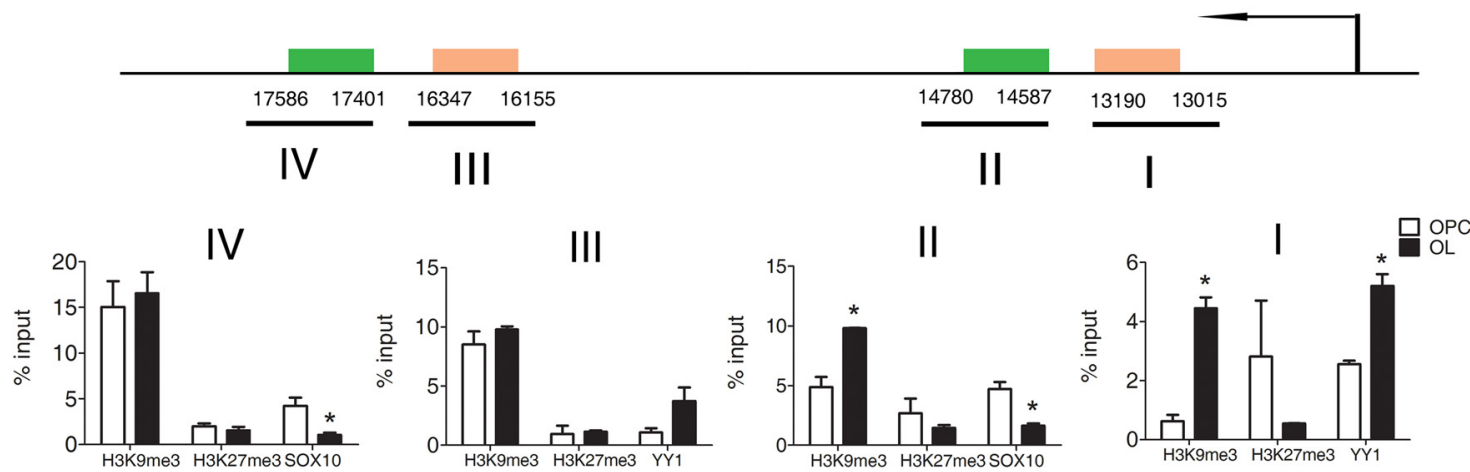

Lhx1
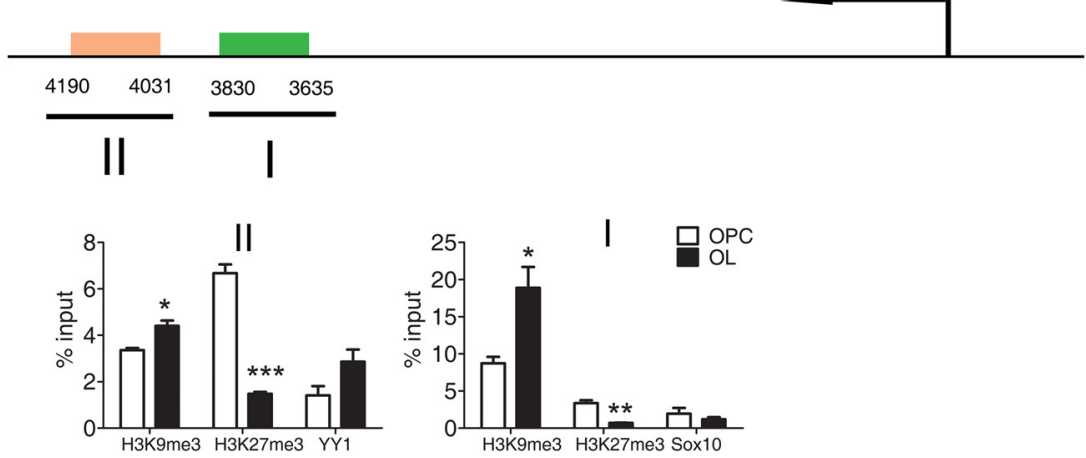

Figure 7. Identification of chromatin modifying complex recruiting H3K9 methyltransferases. $\boldsymbol{a}, \mathrm{A}$ MEME-ChIP analysis was performed to identify the transcription factor binding motifs enriched within the genomic locations characterized by $\mathrm{H3}$ K9me3 unique peak sequences in $\mathrm{OLS}$. Top, Consensus motif for each transcription factor. Bottom, Query motifs. $\boldsymbol{b}$, Western blot analysis to identify the chromatin modifying complex and transcription factors during OPC differentiation using coimmunoprecipitation. C, ChIP of samples isolated from progenitors (OPCs) and differentiating $0 \mathrm{Ls}$ and immunoprecipitated with antibodies against H3K9me3, H3K27me3, YY1, and SOX10. Diagram represents the H3K9me3 peaks identified by ChIP-seq in two genes: one encoding the potassium channel subunit $K c n b 1$ and the other one encoding a neuronal transcription factor (Lhx1). The relative position of the YY1 (pink boxes) and SOX10 binding sites (green boxes) and the regions of DNA (roman numerals) amplified by specific primer pairs are indicated. Arrows mark the TSS. $n=2$ independent cultures. ${ }^{*} p<0.05 .{ }^{* *} p<0.01$. ${ }^{* * *} p<0.001$ (unpaired Student's $t$ test).

fining transcriptional repression and its targets remain undefined. We previously reported the importance of histone deacetylation in repressing transcriptional inhibitors of myelin genes (Shen et al., 2005, 2008b), whereas others defined microRNAs as critical for the transition toward a differentiated phenotype (Dugas et al., 2010). However, deacetylation was a transient and reversible modification of lysine residues on the histone tails, whereas microRNAs serve the purpose of fine-tuning the levels of specific gene products (Shen et al., 2005). Therefore, neither one of these two previously identified epigenetic modifications provided a plausible mechanism underlying the acquisition of a stable cell identity. During the differentiation of ES cells, the loss of pluripotency has been associated with repressive trimethylation of K27 on histone H3 (Bernstein et al., 2006), whereas trimethylation of $\mathrm{K} 9$ has been associated with heterochromatin formation (Volpe et al., 2002). Because differentiation of OPCs into myelinating OLs is characterized by the progressive acquisition of heterochromatin (Liu et al., 2012) and early transcriptional repression of several genes (Swiss et al., 2011), in this study we defined the genome-wide distribu- 
tion of these two repressive histone methylation marks during OL differentiation.

We believe our study contributes to the advancement of our current knowledge of the mechanisms defining OL cell identity in three ways. First, it characterizes the presence of distinct molecular mechanisms repressing multipotentiality and stageinappropriate gene expression. It was previously described that the generation of OPCs from embryonic stem cells was characterized by increased EZH2 activity, which was associated with the repression of genes involved in cell cycle control and neuronal differentiation (Sher et al., 2008; Sher et al., 2012). Our study builds over this knowledge and characterizes the events occurring during the second transition, from OPCs to OLs. Our results clearly indicate that, despite the repressive nature of both H3K9me3 and H3K27me3 mark, they shared only very few target genes in OPCs or in iOLs. The identification of a small set of overlapping genes is consistent with previous studies in Drosophila (Ringrose et al., 2004) and suggests that cells adopt distinctive modalities of gene regulation for regulating specific lineage transitions. The model suggested by our study is that the initial loss of neurogenic ability from neural stem cells to OPC is likely established through repression of neuronal genes by the deposition of H3K27me3 marks by EZH2, which is active at the OPC stage (Sher et al., 2008; Sher et al., 2012), whereas later changes related to decreased excitability of OPCs and differentiation into myelinating OLs are dependent on the deposition of repressive H3K9me3 mark to multiple genomic locations containing genes encoding for ion channels and neurotransmitter signaling molecules. Therefore, our study identifies $\mathrm{H} 3 \mathrm{~K} 9$ trimethylation as the main repressive mechanism of the late lineage transition from OPCs to OLs.

Second, the prominent role of $\mathrm{H} 3 \mathrm{~K} 9 \mathrm{me} 3$ in regulating the expression of functionally related genes led to the question related to the specificity of the recruitment of repressive complex to genomic locations containing the genes of interest. Our analysis revealed that $\mathrm{H} 3 \mathrm{~K} 9 \mathrm{me} 3$ marks were deposited in genomic loci characterized by the presence of cis-sequences enriched for YY1, REST, and SOX binding motifs. We further identified the transcription factors SOX10 and YY1 as integral components of stage-specific repressive complexes, with SOX10 bound to HDAC and HMTs in OPCs and YY1 in OLs. We also identified CoREST, an important cofactor of the transcription factor REST, as part of the complex in OL lineage cells. This finding is consistent with the well-established role of REST to repress sodium channel subunits and other neuronal genes in non-neuronal cells (Ballas et al., 2001; Lunyak et al., 2002). However, when our dataset of $\mathrm{H} 3 \mathrm{~K} 9 \mathrm{me} 3$-associated genes in differentiating OL was overlapped with genes with REST/CoREST binding elements (Abrajano et al., 2009), we only detected a very modest overlap $(<10 \%)$, thereby suggesting that $\mathrm{H} 3 \mathrm{~K} 9$ me3 may serve a much wider role than REST in repressing lineage inappropriate genes in OL. YY1 was previously characterized as a crucial transcription factor for myelination (He et al., 2007) because of its ability to recruit HDAC1 and repress several transcriptional inhibitors of myelin genes (He et al., 2007). SOX family members, in contrast, have been implicated in OL lineage progression, but their role is not completely understood (Stolt et al., 2004; Chew et al., 2010). Our data on the molecular characterization of the complexes regulating the transition from OPC to iOL suggest a model of differentiation that implies loss of repressive complexes containing histone deacetylases, HMTs at SOX binding sites, and concomitant recruitment of the repressive complexes at YY1 binding sites (He et al., 2007). However, we cannot formally rule out the possibility that SOX10 (or another member of the SOX family) may mediate the initial recruitment of repressive complexes to target loci at the OPC stage, whereas the maintenance of a repressive state at these loci may involve other mechanisms. Nevertheless, it is important to notice that genomic locations regulating the expression of ion channels, glutamate receptor subunits, and interacting proteins were characterized by transcriptionally competent chromatin in OPCs, which is consistent with the expression of these gene products and the distinctive electrical properties. Removal of $\mathrm{H} 3 \mathrm{~K} 9 \mathrm{me} 3$ repressive marks by silencing the relevant enzymes in differentiating OLs modified the membrane properties of these cells while altering the expression of several transcripts that were physiologically repressed and silenced during OPC differentiation.

Finally, our results contribute to the currently active debate regarding the multipotential nature of OPCs, by providing a molecular substrate to previously defined controversial issues. Myelinating OLs derive from undifferentiated progenitors with positive immunoreactivity for the surface marker NG2. NG2 cells have been shown to share several properties with neuronal cells. They receive glutamatergic and GABAergic inputs (Bergles et al., 2000; Lin and Bergles, 2004; Ge et al., 2006; Kukley et al., 2007; Ziskin et al., 2007), express glutamate and GABA receptors (Lin and Bergles, 2002), and are able to respond to neurotransmitter release by generating electrical currents (Chittajallu et al., 2004; Káradóttir et al., 2008; De Biase et al., 2010) and modulating proliferation (Gallo et al., 1996), migration (Gudz et al., 2006), and differentiation (Yuan et al., 1998). These unusual properties have distinguished this cell type from other glia, including astrocytes or microglia, and raised the question of whether these OPCs could be a fourth glial type (Nishiyama et al., 2009), with distinct lineage properties and the ability to give rise to neurons. The original reports that NG2 cells could be the precursors not only for OLs but also for neurons (Belachew et al., 2003; Aguirre et al., 2004) were supported by several studies (Rivers et al., 2008; Guo et al., 2010) but negated by others (Dimou et al., 2008; Kang et al., 2010; Zhu et al., 2011) and remain the subject of an active debate, given their abundance in the adult brain and the potential implications for repair not only of demyelinating disorders. This study addresses the question related to lineage plasticity of NG2 cells, by contributing a detailed analysis of the repressive chromatin landscape in OPCs and after differentiation into OLs. Our results suggest that ablation of a single enzyme regulating $\mathrm{H} 3 \mathrm{~K} 9$ methylation is not sufficient to induce an entire lineage switch and that only conditions associated with the removal or stripping of both H3K9me3- and H3K27me3-repressive marks on neuronal genes might modify the lineage commitment of OPCs and result in the generation of neurons. This possibility may require the inactivation of multiple enzymatic activities, as our silencing data reveal a high level of functional redundancy of the HMTs.

In conclusion, this study delineates the functional role of H3K9 and H3K27 methylation in coordinating and ensuring progressive lineage restriction during the enactment of the OPC differentiation program. It highlights the predominant role of $\mathrm{H} 3 \mathrm{~K} 9$ methylation in the successful acquisition of OL cell identity.

\section{References}

Abrajano JJ, Qureshi IA, Gokhan S, Zheng D, Bergman A, Mehler MF (2009) Differential deployment of REST and CoREST promotes glial subtype specification and oligodendrocyte lineage maturation. PLoS One 4:e7665. CrossRef Medline 
Aguirre AA, Chittajallu R, Belachew S, Gallo V (2004) NG2-expressing cells in the subventricular zone are type C-like cells and contribute to interneuron generation in the postnatal hippocampus. J Cell Biol 165:575-589. CrossRef Medline

Ballas N, Battaglioli E, Atouf F, Andres ME, Chenoweth J, Anderson ME, Burger C, Moniwa M, Davie JR, Bowers WJ, Federoff HJ, Rose DW, Rosenfeld MG, Brehm P, Mandel G (2001) Regulation of neuronal traits by a novel transcriptional complex. Neuron 31:353-365. CrossRef Medline

Belachew S, Chittajallu R, Aguirre AA, Yuan X, Kirby M, Anderson S, Gallo V (2003) Postnatal NG2 proteoglycan-expressing progenitor cells are intrinsically multipotent and generate functional neurons. J Cell Biol 161: 169-186. CrossRef Medline

Bergles DE, Roberts JD, Somogyi P, Jahr CE (2000) Glutamatergic synapses on oligodendrocyte precursor cells in the hippocampus. Nature 405:187191. CrossRef Medline

Bernstein BE, Mikkelsen TS, Xie X, Kamal M, Huebert DJ, Cuff J, Fry B, Meissner A, Wernig M, Plath K, Jaenisch R, Wagschal A, Feil R, Schreiber SL, Lander ES (2006) A bivalent chromatin structure marks key developmental genes in embryonic stem cells. Cell 125:315-326. CrossRef Medline

Birgbauer E, Rao TS, Webb M (2004) Lysolecithin induces demyelination in vitro in a cerebellar slice culture system. J Neurosci Res 78:157-166. CrossRef Medline

Bujalka H, Koenning M, Jackson S, Perreau VM, Pope B, Hay CM, Mitew S, Hill AF, Lu QR, Wegner M, Srinivasan R, Svaren J, Willingham M, Barres BA, Emery B (2013) MYRF is a membrane-associated transcription factor that autoproteolytically cleaves to directly activate myelin genes. PLoS Biol 11:e1001625. CrossRef Medline

Cahoy JD, Emery B, Kaushal A, Foo LC, Zamanian JL, Christopherson KS, Xing Y, Lubischer JL, Krieg PA, Krupenko SA, Thompson WJ, Barres BA (2008) A transcriptome database for astrocytes, neurons, and oligodendrocytes: a new resource for understanding brain development and function. J Neurosci 28:264-278. CrossRef Medline

Cartharius K, Frech K, Grote K, Klocke B, Haltmeier M, Klingenhoff A, Frisch M, Bayerlein M, Werner T (2005) MatInspector and beyond: promoter analysis based on transcription factor binding sites. Bioinformatics 21: 2933-2942. CrossRef Medline

Chew LJ, Coley W, Cheng Y, Gallo V (2010) Mechanisms of regulation of oligodendrocyte development by p38 mitogen-activated protein kinase. J Neurosci 30:11011-11027. CrossRef Medline

Chittajallu R, Aguirre A, Gallo V (2004) NG2-positive cells in the mouse white and grey matter display distinct physiological properties. J Physiol 561:109-122. CrossRef Medline

De Biase LM, Nishiyama A, Bergles DE (2010) Excitability and synaptic communication within the oligodendrocyte lineage. J Neurosci 30:36003611. CrossRef Medline

Dimou L, Simon C, Kirchhoff F, Takebayashi H, Götz M (2008) Progeny of Olig2-expressing progenitors in the gray and white matter of the adult mouse cerebral cortex. J Neurosci 28:10434-10442. CrossRef Medline

Dugas JC, Cuellar TL, Scholze A, Ason B, Ibrahim A, Emery B, Zamanian JL, Foo LC, McManus MT, Barres BA (2010) Dicerl and miR-219 Are required for normal oligodendrocyte differentiation and myelination. Neuron 65:597-611. CrossRef Medline

Emery B (2010) Transcriptional and post-transcriptional control of CNS myelination. Curr Opin Neurobiol 20:601-607. CrossRef Medline

Gallo V, Zhou JM, McBain CJ, Wright P, Knutson PL, Armstrong RC (1996) Oligodendrocyte progenitor cell proliferation and lineage progression are regulated by glutamate receptor-mediated $\mathrm{K}^{+}$channel block. J Neurosci 16:2659-2670. Medline

Ge WP, Yang XJ, Zhang Z, Wang HK, Shen W, Deng QD, Duan S (2006) Long-term potentiation of neuron-glia synapses mediated by $\mathrm{Ca}^{2+}$ permeable AMPA receptors. Science 312:1533-1537. CrossRef Medline

Gudz TI, Komuro H, Macklin WB (2006) Glutamate stimulates oligodendrocyte progenitor migration mediated via an alphav integrin/myelin proteolipid protein complex. J Neurosci 26:2458-2466. CrossRef Medline

Guo F, Maeda Y, Ma J, Xu J, Horiuchi M, Miers L, Vaccarino F, Pleasure D (2010) Pyramidal neurons are generated from oligodendroglial progenitor cells in adult piriform cortex. J Neurosci 30:12036-12049. CrossRef Medline

He Y, Dupree J, Wang J, Sandoval J, Li J, Liu H, Shi Y, Nave KA, Casaccia-
Bonnefil P (2007) The transcription factor Yin Yang 1 is essential for oligodendrocyte progenitor differentiation. Neuron 55:217-230. CrossRef Medline

Huang da W, Sherman BT, Lempicki RA (2009a) Bioinformatics enrichment tools: paths toward the comprehensive functional analysis of large gene lists. Nucleic Acids Res 37:1-13. CrossRef Medline

Huang da W, Sherman BT, Lempicki RA (2009b) Systematic and integrative analysis of large gene lists using DAVID bioinformatics resources. Nat Protoc 4:44-57. CrossRef Medline

Kang SH, Fukaya M, Yang JK, Rothstein JD, Bergles DE (2010) $\mathrm{NG}^{2+} \mathrm{CNS}$ glial progenitors remain committed to the oligodendrocyte lineage in postnatal life and following neurodegeneration. Neuron 68:668-681. CrossRef Medline

Káradóttir R, Hamilton NB, Bakiri Y, Attwell D (2008) Spiking and nonspiking classes of oligodendrocyte precursor glia in CNS white matter. Nat Neurosci 11:450-456. CrossRef Medline

Kharchenko PV, Tolstorukov MY, Park PJ (2008) Design and analysis of ChIP-seq experiments for DNA-binding proteins. Nat Biotechnol 26: 1351-1359. CrossRef Medline

Kubicek S, O'Sullivan RJ, August EM, Hickey ER, Zhang Q, Teodoro ML, Rea S, Mechtler K, Kowalski JA, Homon CA, Kelly TA, Jenuwein T (2007) Reversal of $\mathrm{H} 3 \mathrm{~K} 9 \mathrm{me} 2$ by a small-molecule inhibitor for the G9a histone methyltransferase. Mol Cell 25:473-481. CrossRef Medline

Kukley M, Capetillo-Zarate E, Dietrich D (2007) Vesicular glutamate release from axons in white matter. Nat Neurosci 10:311-320. CrossRef Medline

Langmead B, Trapnell C, Pop M, Salzberg SL (2009) Ultrafast and memoryefficient alignment of short DNA sequences to the human genome. Genome Biol 10:R25. CrossRef Medline

Lin SC, Bergles DE (2002) Physiological characteristics of NG2-expressing glial cells. J Neurocytol 31:537-549. CrossRef Medline

Lin SC, Bergles DE (2004) Synaptic signaling between GABAergic interneurons and oligodendrocyte precursor cells in the hippocampus. Nat Neurosci 7:24-32. CrossRef Medline

Liu J, Dietz K, DeLoyht JM, Pedre X, Kelkar D, Kaur J, Vialou V, Lobo MK, Dietz DM, Nestler EJ, Dupree J, Casaccia P (2012) Impaired adult myelination in the prefrontal cortex of socially isolated mice. Nat Neurosci 15:1621-1623. CrossRef Medline

Lunyak VV, Burgess R, Prefontaine GG, Nelson C, Sze SH, Chenoweth J, Schwartz P, Pevzner PA, Glass C, Mandel G, Rosenfeld MG (2002) Corepressor-dependent silencing of chromosomal regions encoding neuronal genes. Science 298:1747-1752. CrossRef Medline

Machanick P, Bailey TL (2011) MEME-ChIP: motif analysis of large DNA datasets. Bioinformatics 27:1696-1697. CrossRef Medline

Marin-Husstege M, Muggironi M, Liu A, Casaccia-Bonnefil P (2002) Histone deacetylase activity is necessary for oligodendrocyte lineage progression. J Neurosci 22:10333-10345. Medline

McCabe MT, Ott HM, Ganji G, Korenchuk S, Thompson C, Van Aller GS, Liu Y, Graves AP, Della Pietra A 3rd, Diaz E, LaFrance LV, Mellinger M, Duquenne C, Tian X, Kruger RG, McHugh CF, Brandt M, Miller WH, Dhanak D, Verma SK, et al. (2012) EZH2 inhibition as a therapeutic strategy for lymphoma with EZH2-activating mutations. Nature 492: 108-112. CrossRef Medline

McLean CY, Bristor D, Hiller M, Clarke SL, Schaar BT, Lowe CB, Wenger AM, Bejerano G (2010) GREAT improves functional interpretation of cis-regulatory regions. Nat Biotechnol 28:495-501. CrossRef Medline

Miron VE, Ludwin SK, Darlington PJ, Jarjour AA, Soliven B, Kennedy TE, Antel JP (2010) Fingolimod (FTY720) enhances remyelination following demyelination of organotypic cerebellar slices. Am J Pathol 176:26822694. CrossRef Medline

Nishiyama A, Komitova M, Suzuki R, Zhu X (2009) Polydendrocytes (NG2 cells): multifunctional cells with lineage plasticity. Nat Rev Neurosci 10: 9-22. CrossRef Medline

Rice JC, Allis CD (2001) Histone methylation versus histone acetylation: new insights into epigenetic regulation. Curr Opin Cell Biol 13:263-273. CrossRef Medline

Richardson WD, Young KM, Tripathi RB, McKenzie I (2011) NG2-glia as multipotent neural stem cells: fact or fantasy? Neuron 70:661-673. CrossRef Medline

Ringrose L, Ehret H, Paro R (2004) Distinct contributions of histone H3 lysine 9 and 27 methylation to locus-specific stability of polycomb complexes. Mol Cell 16:641-653. CrossRef Medline 
Rivers LE, Young KM, Rizzi M, Jamen F, Psachoulia K, Wade A, Kessaris N, Richardson WD (2008) PDGFRA/NG2 glia generate myelinating oligodendrocytes and piriform projection neurons in adult mice. Nat Neurosci 11:1392-1401. CrossRef Medline

Schaefer A, Sampath SC, Intrator A, Min A, Gertler TS, Surmeier DJ, Tarakhovsky A, Greengard P (2009) Control of cognition and adaptive behavior by the GLP/G9a epigenetic suppressor complex. Neuron 64:678-691. CrossRef Medline

Shechter D, Dormann HL, Allis CD, Hake SB (2007) Extraction, purification and analysis of histones. Nat Protoc 2:1445-1457. CrossRef Medline

Shen S, Li J, Casaccia-Bonnefil P (2005) Histone modifications affect timing of oligodendrocyte progenitor differentiation in the developing rat brain. J Cell Biol 169:577-589. CrossRef Medline

Shen S, Liu A, Li J, Wolubah C, Casaccia-Bonnefil P (2008a) Epigenetic memory loss in aging oligodendrocytes in the corpus callosum. Neurobiol Aging 29:452-463. CrossRef Medline

Shen S, Sandoval J, Swiss VA, Li J, Dupree J, Franklin RJ, Casaccia-Bonnefil P (2008b) Age-dependent epigenetic control of differentiation inhibitors is critical for remyelination efficiency. Nat Neurosci 11:1024-1034. CrossRef Medline

Sher F, Rössler R, Brouwer N, Balasubramaniyan V, Boddeke E, Copray S (2008) Differentiation of neural stem cells into oligodendrocytes: involvement of the polycomb group protein Ezh2. Stem Cells 26:28752883. CrossRef Medline

Sher F, Boddeke E, Olah M, Copray S (2012) Dynamic changes in Ezh2 gene occupancy underlie its involvement in neural stem cell self-renewal and differentiation towards oligodendrocytes. PLoS One 7:e40399. CrossRef Medline

Stolt CC, Lommes P, Friedrich RP, Wegner M (2004) Transcription factors Sox8 and Sox10 perform non-equivalent roles during oligodendrocyte development despite functional redundancy. Development 131:23492358. CrossRef Medline

Swiss VA, Nguyen T, Dugas J, Ibrahim A, Barres B, Androulakis IP, Casaccia $P$ (2011) Identification of a gene regulatory network necessary for the initiation of oligodendrocyte differentiation. PLoS One 6:e18088. CrossRef Medline
Thorvaldsdóttir H, Robinson JT, Mesirov JP (2013) Integrative Genomics Viewer (IGV): high-performance genomics data visualization and exploration. Brief Bioinform 14:178-192. Medline

Volpe TA, Kidner C, Hall IM, Teng G, Grewal SI, Martienssen RA (2002) Regulation of heterochromatic silencing and histone H3 lysine-9 methylation by RNAi. Science 297:1833-1837. CrossRef Medline

Wu M, Hernandez M, Shen S, Sabo JK, Kelkar D, Wang J, O’Leary R, Phillips GR, Cate HS, Casaccia P (2012) Differential modulation of the oligodendrocyte transcriptome by sonic hedgehog and bone morphogenetic protein 4 via opposing effects on histone acetylation. J Neurosci 32:66516664. CrossRef Medline

Yuan X, Eisen AM, McBain CJ, Gallo V (1998) A role for glutamate and its receptors in the regulation of oligodendrocyte development in cerebellar tissue slices. Development 125:2901-2914. Medline

Yuan X, Chittajallu R, Belachew S, Anderson S, McBain CJ, Gallo V (2002) Expression of the green fluorescent protein in the oligodendrocyte lineage: a transgenic mouse for developmental and physiological studies. J Neurosci Res 70:529-545. CrossRef Medline

Yu Y, Chen Y, Kim B, Wang H, Zhao C, He X, Liu L, Liu W, Wu LM, Mao M, Chan JR, Wu J, Lu QR (2013) Olig2 targets chromatin remodelers to enhancers to initiate oligodendrocyte differentiation. Cell 152:248-261. CrossRef Medline

Zhang Y, Liu T, Meyer CA, Eeckhoute J, Johnson DS, Bernstein BE, Nusbaum C, Myers RM, Brown M, Li W, Liu XS (2008) Model-based analysis of ChIP-Seq (MACS). Genome Biol 9:R137. CrossRef Medline

Zhang Y, Chen K, Sloan SA, Bennett ML, Scholze AR, O'Keeffe S, Phatnani HP, Guarnieri P, Caneda C, Ruderisch N, Deng S, Liddelow SA, Zhang C, Daneman R, Maniatis T, Barres BA, Wu JQ (2014) An RNA-sequencing transcriptome and splicing database of glia, neurons, and vascular cells of the cerebral cortex. J Neurosci 34:11929-11947. CrossRef Medline

Zhu X, Hill RA, Dietrich D, Komitova M, Suzuki R, Nishiyama A (2011) Age-dependent fate and lineage restriction of single NG2 cells. Development 138:745-753. CrossRef Medline

Ziskin JL, Nishiyama A, Rubio M, Fukaya M, Bergles DE (2007) Vesicular release of glutamate from unmyelinated axons in white matter. Nat Neurosci 10:321-330. CrossRef Medline 